NBER WORKING PAPER SERIES

\title{
YOU GET WHAT YOU PAY FOR: SCHOOLING INCENTIVES AND CHILD LABOR
}

\author{
Eric V. Edmonds \\ Maheshwor Shrestha \\ Working Paper 19279 \\ http://www.nber.org/papers/w19279
NATIONAL BUREAU OF ECONOMIC RESEARCH
1050 Massachusetts Avenue
Cambridge, MA 02138
August 2013

The authors are grateful to the Nepal Goodweave Foundation and New ERA Ltd. for their assistance with this project and to Max Mucenic and Jayakrishna Upadhyay for research assistance. This study has benefited from the constructive input of Jagat Basnet, Charita Castro, Lauren Damme, Pablo Diego Rossell, Marcia Eugenio, Art Hansen, Ronaldo Iachan, Leigh Linden, Angie Peltzer, Lubha Raj Neupane, Amy Ritualo, Brandie Sasser, Ghanshyam Shrestha, Nina Smith, and Elizabeth Wolkomir as well as participants at NEUDC and seminars at Bocconi University, Stockholm University, the U.S. Department of Labor, the University of Bologna, and the University of Connecticut. Funding for this research was provided by Dartmouth College and the United States Department of Labor under Cooperative Agreement (IL-16565-07-75-K). Edmonds and Shrestha both wish to disclose that they received financial support from the U.S. Department of Labor (through ICF International) related to this project for parts of the project completed before September 2011. Portions of this paper draw on our report prepared for the U.S. Department of Labor. This study was prepared independently without review or editing from Goodweave or the U.S. Department of Labor. This study does not reflect the views or policies of the United States Department of Labor, nor does the mention of trade names, commercial products, or organizations imply endorsement by the United States Government. Any errors, omissions or oversights are ours alone. Edmonds wishes to disclose that he has received significant financial support from the U.S. Department of Labor, ICF International, the International Labor Organization, and UNICEF for consulting services related to child labor. Edmonds also serves as an unpaid advisor to the Goodweave Foundation, the NGO providing services as a part of this study. The views expressed herein are those of the authors and do not necessarily reflect the views of the National Bureau of Economic Research.

NBER working papers are circulated for discussion and comment purposes. They have not been peerreviewed or been subject to the review by the NBER Board of Directors that accompanies official NBER publications.

(C) 2013 by Eric V. Edmonds and Maheshwor Shrestha. All rights reserved. Short sections of text, not to exceed two paragraphs, may be quoted without explicit permission provided that full credit, including (C) notice, is given to the source. 
You Get What You Pay For: Schooling Incentives and Child Labor

Eric V. Edmonds and Maheshwor Shrestha

NBER Working Paper No. 19279

August 2013

JEL No. J22,J88,O15

\begin{abstract}
Can efforts to promote education deter child labor? We report on the findings of a field experiment where a conditional transfer incentivized the schooling of children associated with carpet factories in Nepal. We find that schooling increases and child involvement in carpet weaving decreases when schooling is incentivized. As a simple static labor supply model would predict, we observe that treated children resort to their counterfactual level of school attendance and carpet weaving when schooling is no longer incentivized. From a child labor policy perspective, our findings imply that "You get what you pay for" when schooling incentives are used to combat hazardous child labor.
\end{abstract}

Eric V. Edmonds

Department of Economics

Dartmouth College

6106 Rockefeller Hall

Hanover, NH 03755

and NBER

Eric.V.Edmonds@Dartmouth.edu

Maheshwor Shrestha

Massachusetts Institute of Technology

50 Memorial Drive

E52-391

Cambridge, MA 02142

mahesh68@mit.edu 


\title{
You Get What You Pay For: Schooling Incentives and Child
}

\section{Labor}

\author{
Eric V. Edmonds and Maheshwor Shrestha*
}

July 12, 2013

\begin{abstract}
Can efforts to promote education deter child labor? We report on the findings of a field experiment where a conditional transfer incentivized the schooling of children associated with carpet factories in Nepal. We find that schooling increases and child involvement in carpet weaving decreases when schooling is incentivized. As a simple static labor supply model would predict, we observe that treated children resort to their counterfactual level of school attendance and carpet weaving when schooling is no longer incentivized. From a child labor policy perspective, our findings imply that "You get what you pay for" when schooling incentives are used to combat hazardous child labor.
\end{abstract}

An estimated 306 million children 5-17 were economically active in the world in 2008. 115 million were working in activities considered hazardous in their country of residence by virtue of the activity's nature or circumstance (International Labour Organization 2010). This study considers whether involvement in a hazardous form of child labor can be influenced by schooling incentives. This is an important policy question as combating child labor through education promotion has been the centerpiece of global anti child labor policy since 2001円 The relationship between schooling incentives and child labor is of academic interest as

*Edmonds: : Department of Economics, Dartmouth College, 6106 Rockefeller Hall, Hanover NH 03755 (email: eedmonds@dartmouth.edu); Shrestha: Department of Economics, Massachusetts Institute of Technology, 50 Memorial Drive, E52-391, Cambridge MA 02142 (email: mahesh68@mit.edu). The authors are grateful to the Nepal Goodweave Foundation and New ERA Ltd. for their assistance with this project and to Max Mucenic and Jayakrishna Upadhyay for research assistance. This study has benefited from the constructive input of Jagat Basnet, Charita Castro, Lauren Damme, Pablo Diego Rossell, Marcia Eugenio, Art Hansen, Ronaldo Iachan, Leigh Linden, Angie Peltzer, Lubha Raj Neupane, Amy Ritualo, Brandie Sasser, Ghanshyam Shrestha, Nina Smith, and Elizabeth Wolkomir as well as participants at NEUDC and seminars at Bocconi University, Stockholm University, the U.S. Department of Labor, the University of Bologna, and the University of Connecticut. Funding for this research was provided by Dartmouth College and the United States Department of Labor under Cooperative Agreement (IL-16565-07-75-K). Portions of this paper draw on our report prepared for the U.S. Department of Labor (ICF International 2012). This study was prepared independently without review or editing from Goodweave or the U.S. Department of Labor. This study does not reflect the views or policies of the United States Department of Labor, nor does the mention of trade names, commercial products, or organizations imply endorsement by the United States Government. Any errors, omissions or oversights are ours alone.

${ }^{1}$ The U.S. Department of Labor (DOL) is the largest funder of anti-child labor programs around the world. The office in the U.S. Department of Labor (DOL) charged with child labor abroad alone has appropriated $\$ 800$ million to 258 projects 
well with implications for the theoretical and empirical literature on the determinants of child labor supply and the literature on how opportunity costs influence schooling decisions.

We have an abundance of evidence that schooling incentives such as conditional cash transfers can promote school attendance, but there are important unanswered questions related to child labor. Conditional transfers can reduce common forms of child work (Barrera-Osorio et al. 2011, Behrman et al. 2011, Maluccio \& Flores 2005, Schady \& Araujo 2006). However, the magnitudes of the decline in work do not correspond to the increase in schooling Attanasio et al. 2010, Dammert 2009, Duryea \& Morrison 2004, Galiani \& McEwan 2011). This has lead some to question whether there is a trade-off between common forms of work and schooling (e.g. Ravallion \& Wodon (2000)), a question that is difficult to test directly given the joint nature of school and work decisions. It is also not obvious whether these results extrapolate to populations vulnerable to the hazardous forms of child labor that are the focus of policy.

The recent academic literature on child labor supply rarely finds evidence that child labor supply is responsive to its return relative to schooling. First, the theoretical literature on child labor supply emphasizes the primacy of living standards in influencing time allocation. For example, the canonical child labor model of Basu \& Van (1998) is built on the luxury axiom which posits that children work when their family cannot meet its basic needs otherwise, regardless of how large or small the return to child labor is. Baland \& Robinson (2000) and Ranjan (2001) highlight that constraints on liquidity drive child labor even when relative prices suggest that alternatives are preferred uses of child time. Second, the empirical evidence on the determinants of child labor emphasizes the responsiveness of child labor to changes in family living standards beyond any other factor. An extreme example is Edmonds \& Schady (2012) where a $\$ 15$ per month transfer in Ecuador induces households to forego $\$ 80$ a month in child labor earnings. Other studies emphasize the importance of child labor in coping with transitory shocks when returns to child labor are presumably lower (Beegle et al. 2006, Duryea et al. 2007, Jacoby \& Skoufias 1997). In contrast, there is little evidence of a response of child labor supply to its net return. Even studies of large economic restructuring where there should be substantive changes in the employment opportunities open to children typically only find effects on child labor through family living standards (Cogneau \& Jedwab 2012, Dammert 2008, Edmonds \& Pavcnik 2005, Edmonds et al. 2010).

Hazardous child labor may also be fundamentally different from more common forms of work. First, selection into hazardous child labor may be such that only the most desperate select into it, implying that their labor supply may be especially inelastic to changes in net returns (Dessy \& Pallage 2005). Second,

in 91 countries since the office's creation in 1995. The influence of DOL far exceeds these appropriations as often DOL is a contributing partner in larger projects or the experience of DOL informs the design of other, non-DOL projects. In 2001, DOL launched the Child Labor Education Initiative (EI) that placed the promotion of education at the center of project tools to combat hazardous child labor. 
it is not obvious that schooling is the counterfactual use of time of children in hazardous child labor. It could be that non-hazardous employment is the counterfactual use of child time to hazardous employment. Hence, hazardous employment would not be elastic to schooling returns in the same was as non-hazardous employment where schooling is the counterfactual use of time. Third, agency issues may mitigate the responsiveness of hazardous child labor to changes in the local economic environment (Rogers \& Swinnerton 2008). In usual labor supply models, labor is free to adjust in response to changes in relative prices. Children in general have limited agency to adjust their own labor supply. In our context, two-thirds of subjects are migrants. Their agency could be limited if the agent making decisions over child labor (head of the family) may be at their origin and thus removed from the circumstances of employment such that child employment may not change in response to changes in circumstances.

We consider this question of the link between schooling incentives and child labor through a schooling promotion project for children associated with workers in the handmade export-oriented carpet sector of the Kathmandu Valley of Nepal. A lottery was used to allocate 660 children to three groups:

1. A control group whose schooling and time allocation would be monitored but would receive no education support.

2. A scholarship group whose education related expenses would be paid directly or reimbursed up to a cap.

3. A stipend group that received the scholarship treatment plus an additional stipend conditional on schooling attendance. The stipend was paid as a credit in a local shop that could be used towards food.

The treatments lasted one academic year. The design was motivated by our NGO partner's desire to test whether a conditional stipend would improve the impact of the existing scholarship program (the group 2 treatment) that they were administering to a separate population.

We find that the response to these treatment concord with the predictions of a static labor supply model. The scholarship treatment is associated with increase in school enrollment during the year of support and an increase in attendance at the start of the year. Its effects fade out as funds are exhausted. The stipend treatment has large effects on school attendance and achievement during the period of support. Associated with the stipend's effects on attendance, we document a decline in child involvement in carpet weaving, a hazardous form of child labor. These effects of the stipend treatment dissipate when schooling is no longer incentivized. After the end of the period of support, we find no evidence of an effect of either the stipend or scholarship treatments on schooling or carpet weaving. 
These findings have important implications for child labor policy. This is the first field experiment targeted at a population vulnerable to child labor (and was funded by the U.S. Department of Labor as a pilot for using field experiments to improve child labor policy). Since 2001, the promotion of education has been central in efforts to reduce hazardous child labor around the world. Despite the policy focus, we have little direct evidence of a connection between child labor and the net return to education. Our findings reject the hypothesis that net returns to schooling do not influence hazardous child labor and highlight the potential for education support projects to deter hazardous child labor among beneficiaries through decreasing the cost of schooling.

That said, our findings also illustrate that transitory education support, as is required for USG funded projects $2^{2}$ may not affect schooling and child labor beyond the period of support. Current policy is based on the premise that there are permanent effects of transitory support. First, there is the hope that the impact of the support will endure. For example, if liquidity constrained families pull children out of school in response to temporary shocks, but some cost of rejoining school prevents children from going to school after the temporary shock has abated (as in De Janvry et al.|2006), the temporary support can have lasting effects by buffering the temporary shock. Second, permanent-income theory suggests that the marginal propensity to consume out of transitory income should be zero. Hence, the recipients should smooth the impact of transitory support over time. In our study context, we do not find any impact of schooling support on schooling and child labor even after a year past the completion of the program.

Our findings also have important implications for the modeling of child time allocation. The first models of human capital such as Schultz (1960) essentially adapt the static labor supply model to discuss the tradeoff between employment opportunities and schooling. As discussed above, the simple static labor supply model is rarely used in the child labor literature for the last two decades. Similarly, the recent literature on educational decisions rarely use the framework Schultz and colleagues developed (for recent examples: Duflo (2001), Jensen (2010), Bursztyn \& Coffman (2012)), and as mentioned above, there is even a debate about the extent to which work has a meaningful effect on schooling. Our findings on subject responses to the two treatments follow the predictions of the static labor supply model where foregone earnings are an important source of schooling costs. Our results then illustrate the usefulness of the static child labor supply model for the analysis of schooling and child labor decisions (of course, not to the exclusion of other models). Importantly, this study is not consistent with the view that hazardous forms of child labor are fundamentally different or require a distinct modeling or policy approach.

\footnotetext{
${ }^{2}$ USG rules constrain projects to a maximum of 5 years. Our informal review of recent USG solicitations specifically targeted at child labor suggests 3 years is common at the solicitation stage. A 3 year contract would translate into at most 2 years of support for children as 3 years would include both start up and reporting time. The project examined below was solicited as 3 years, extended to 5 , and provided 1 year of support to children identified as vulnerable to child labor.
} 


\section{Background}

\subsection{Study Population}

Handmade carpets are Nepal's leading export. Nepal exports high-quality hand-knotted carpets to the U.S. and European markets. Child labor in carpet weaving might be the only way U.S. consumers interact with products made with child labor in Nepal. Child labor in Nepali carpets became a major policy issue in the mid 1990s because of working conditions in weaving as well as evidence of human trafficking and forced labor. This study is part of a project funded by the U.S. Department of Labor aimed at understanding child labor in the carpet sector of Nepal with the policy goal of eliminating it for children under $183^{3}$ Under the international convention governing regulation of worst forms of child labor (ILO C182), every country is charged with making a list of hazardous child labor in the country for prohibition for children below 18 . Carpet weaving is on the Nepali government's list of hazardous child labor in Nepal. There are an estimated 10,907 children employed in the hand-made export-oriented carpet sector of Nepal out of a total labor force of 49,538 (ICF 2012$)$.

Our NGO partner in the study is the Nepali Goodweave Foundation (NGF), formerly known as Rugmark. NGF certifies individual carpets as child labor free and provides support services to children found in establishments involved in the manufacture of certified carpets. NGF selected 101 establishments in the Kathmandu Valley for this study. The 101 establishments were NGF licensees or subcontractors of NGF licensees as of January 2010. 100 of these establishments engaged in weaving, with one establishment reporting finishing work and dyeing wool but no weaving. These 101 establishments had a total of 3,434 employees as of January 2010 and had completed a total of 8,464 square meters of carpet in the last 30 days. For this study, NGF selected 660 children 10-16 associated with carpet manufacturing establishments that (a) had attended school within the last 18 months, (b) had not received education support from NGF or other sponsors and (c) were in families who faced an elevated risk of transitioning to child labor. NGF views children as having an elevated risk of transitioning to child labor if they met at least one of the following three criteria:

- Family size: A family with 3 or more school aged children in residence;

- Family income: Total monthly family income (including monetary support from kin/relatives living elsewhere) of NPR 8,500 (USD 119) if housing was not provided free of charge by an establishment or of NPR 7,000 if housing was provided free of charge by the establishment;

\footnotetext{
${ }^{3}$ While the applicable international conventions imply that hazardous forms of child labor should be prohibited for children under 18, Nepali law prohibits child involvement in carpet weaving for children under 16 . Hence, children 16 and 17 are legally allowed to weave in Nepal.
} 
- Sibling schooling: Families with 1 or fewer children attending school or families with a child who dropped out before completing grade $8 \longdiv { 4 }$

These criteria for identifying a child as vulnerable to child labor were chosen by NGF based on the field experience of their inspectors in its sponsored education program (essentially the scholarship treatment). Most subjects vulnerable to child labor are not engaged in child labor (less than 10 percent of subjects weave at baseline). The income criteria were also based on the minimum wage set by the government of Nepal and in effect in early 2010. The minimum wage is viewed by the government of Nepal as the minimum income needed for subsistence. The minimum wage level per person was NPR 4,600 per month. Assuming 85 percent of children lived in households with an adult earner implied an income of NPR 8,500 per month. The allowance of NPR 1,500 per month for rent when housing was provided free of charge by employers was based on the NGF inspectors' subjective opinion on the value of this free housing. The decision to limit subjects to those recently enrolled in school was based on NGF's opinion that children out of school for longer would require transition education services and other types of support to re-enter school after a long absence.

NGF conducted preliminary interviews with workers in carpet establishments to collect data on the children they have, their family income and other information necessary to determine eligibility of the children. For the 660 children in this study, Table 1 contains counts of the number of subjects who met each of the criteria listed above. All study subjects were 10-16, had attended school within the last 18 months, and did not receive other education support. Subjects could match multiple criteria. Two-thirds of study subjects met at least two criteria. Only 30 study subjects did not meet the low income criterion. Of these 30, 1 was in the study because of sibling dropouts, 3 were in the study because 1 or fewer siblings attend school, and the remaining 27 met the family size criteria, having 3 or more eligible children in the family.

Table2 2 contains a comparison of the study population to children 10-16 in the country, in the Kathmandu Valley and living in households below the national poverty line in the Nepal Living Standards SurveyIII (NLSS-III) of 2010/11. Our pool is more Buddhist and of Tamang and Magar ethnicity than other populations within the country 5 Our study pool is also younger and more likely to be female than a random sample of children in either of these populations. The mothers and fathers have lower educational attainment compared to population in the Kathmandu valley (including poor households) and the national population. Parental education and literacy is similar to or slightly better than that of the national population living in poverty although not compared to poor households in Kathmandu. Fathers are less likely to be present in

\footnotetext{
${ }^{4}$ Basic education (grades 1 through 8 ) is free in community (government) schools of Nepal

${ }^{5}$ The carpet exporting industry in Nepal was initially set up amongst Tibetan refugees in Kathmandu. The ethno-linguistic similarity between Tibetan and Tamang and Magar ethnicities explain why these ethnicities and religion are predominant in the carpet sector of Nepal.
} 
our study population than other populations. To the extent that mothers and fathers respond differently to schooling incentives, findings could differ in our sample compared to a sample where fathers are impacted by schooling incentives. Schooling is more prevalent in our sample although completed education is lower. Importantly, while slightly less than 10 percent of our sample is involved in weaving at baseline in our sample, participation in this hazardous form of child labor is more prevalent than wage employment in general among the poor in the Kathmandu Valley.

\subsection{Program Description}

The primary purpose of the Schooling Incentives Project Evaluation (SIPE) study was to evaluate the impact of scholarship and stipend programs in encouraging school enrollment and attendance and reducing child labor in the carpet sector in Nepal. SIPE was the first randomized controlled trial (RCT) impact evaluation of a child labor and schooling intervention to be conducted in Nepal. Subjects were identified in February 2010 and received schooling support for the school year beginning in April 2010 and ending March 2011.

NGF designed and implemented SIPE with technical support from the authors 6 NGF's involvement in the project was motivated by a desire to improve the efficacy of its efforts to prevent children working on looms. The 660 study subjects were grouped into gender - age - establishment size cells, and randomization was used to assign subjects in each cell to one of three groups:

1. Group \#1 is the control group. The children in group 1 received no schooling-related assistance.

2. Group \#2 is the scholarship group. The children in group 2 received a scholarship benefit. NGF reimbursed or paid each child's schooling-related costs up to a maximum of (Nepali rupees) NPR 3,950 per year. This assistance could include all schooling-related costs such as fees, tuition, uniforms, books and other supplies. Once the scholarship funds were exhausted, no additional support was available to subjects from NGF. This treatment arm was modeled after NGF's Sponsored Education Program 7 Our calculations from the Nepal Living Standards Survey 2003/04 (NLSS) suggested that this scholarship amount was sufficient to cover schooling costs for children if they attended community or government schools in the Kathmandu Valley.

3. Group \#3 is the stipend group. The children in group 3 received the scholarship as group 2 and an additional stipend. In addition to the scholarship, NGF provided a stipend of food rations valued at

\footnotetext{
${ }^{6}$ ICF International executed SIPE under its "Research on Children Working in the Carpet Industry of India, Nepal, and Pakistan" contract with the U.S. Department of Labor. NGF, New ERA, and the authors (through International Child Action Research and Evaluation LLC) were all sub-contractors to ICF for this contract. Leigh Linden was an important contributor to the early discussions of this project, in addition to providing invaluable input on an earlier draft of this paper.

${ }^{7}$ The scholarship amount, NPR 3,950, was the yearly average cost for supporting one child through the NGF's own school support project in year 2008 .
} 
NPR 1,000 per month per child provided that the child attended school at least 80 percent of the days his or her school was open for teaching. The stipend distribution occurred through local stores. Every child that received the stipend was given an identity card with a picture of the child and their guardian. NGF identified several local stores in the neighborhood of the recipients' residences and arranged for the holder of the identity card to receive the stipend as an in-store credit when the child met the school attendance requirements 8 Families in the poorest third of the population of the Kathmandu Valley spend slightly more than NPR 1,000 per month on grains and pulses. Hence, we do not anticipate significant distortions from the stipend's payment as an in-store credit. The amount of the stipend is a third of the cash earnings made by a youth in weaving and roughly the same as a child would earn working as a domestic, a common occupation of migrant children in Kathmandu.

All subjects assigned to the two treatment arms took up the benefits when offered. Although group 3 receives both the scholarship treatment and the additional stipend, we refer to group 3 as the stipend group for economy.

Subjects appear comparable across treatment arms. Table 3 summarizes background characteristics of study subjects by treatment status using data collected before the assignment of subjects to treatment arms. Column 1 contains the control population mean and (in parenthesis) standard deviation for the attribute indicated by the row. Column 2 contains the differences between the scholarship treatment group and the control group and the standard error of this difference in parenthesis. For example, the average subject age in the control group is 11.86 and 11.91 in the scholarship (group 2) arm. Column 3 contains the difference between the stipend group (group 3) and the control group as well as the standard error of this difference. Column 4 is the difference between the scholarship treatment group and the stipend treatment group and the standard error of that difference. The bottom rows of the table contain the F-Stat and P-Value associated with the null that the individual differences in the column are jointly zero.

There are no statistically significant differences across characteristics, and to our eyes, none of the differences appear substantive either. A few characteristics in Table 4 merit explanation. NGF works with children associated with licensee establishments. The average associated establishment has 41 employees. All subjects will have a caregiver involved in carpet manufacture but fewer than 1 in 10 subjects weave themselves and 98 percent have gone to school at some point in the academic year prior to treatment. 59 percent of subjects live inside the worksite usually with 3.6 other family members present. 66 percent were born elsewhere and 66 percent have both parents present.

\footnotetext{
${ }^{8}$ At the time of the project, USG projects were restricted from providing direct cash payments to beneficiaries in foreign countries. Hence, the stipend had to be delivered as a credit. Most recipients bought rice with the credit.
} 


\section{Empirical Methods}

\subsection{Timeline}

The two treatments in SIPE were provided to subjects during the school year that began in April 2010 and ended in March 2011. Table 4 reviews the timeline of data collection which spanned February 2010 to August 2012 as well as the project. There are two providers for the data used in this study. NGF and New ERA Ltd. New ERA is a Nepali data collection firm contracted to provide independent data collection. All data provided by NGF is collected by agents who are informed of a subject's status in the intervention. New ERA was explicitly independent of the evaluation. New ERA enumerators were not aware of a subject's status in the intervention or the details of the intervention.

NGF provides two sources of data used in this study. First, they conducted an eligibility survey in early February 2010 that was used to identify subjects, allocate subjects to cells for randomization, and test the validity of the randomization. Second, NGF collected schooling records for the purpose of documenting compliance with the attendance requirements for the stipend intervention. We refer to these data as NGF School Records. They are attractive in our evaluation, because they contain monthly school attendance records for every child from April 2010 until March 2011 as well as yearend in-school test scores. These school attendance records were used by NGF to determine program eligibility.

New ERA provides four surveys used in this study. The baseline survey was conducted before subjects were informed about their status in the project in March 2010. The data were not available prior to random assignment so only the NGF eligibility survey was accessible at the time of randomization. Both subjects and their adult caregivers were interviewed in the baseline survey. The midterm survey was conducted in September 2010, before the October holidays. Only adult caregivers were interviewed in the midterm survey. The number of questions was reduced compared to the baseline survey, and no questions about child involvement in the carpet sector were collected. The yearend survey was conducted after New Year festivities in April and May of 2011. Adult caregivers and subjects were interviewed more than a month after the final distribution of benefits. The yearend survey instrument was nearly identical to the baseline instrument. The post survey was conducted in August 2012, approximately 17 months after the final distribution of benefits. A streamlined instrument was administered to adult caregivers.

\section{$2.2 \quad$ Empirics}

The SIPE study was small in scale because of limited resources. The sample size was chosen to have statistical power with regards to answering one question. Specifically, SIPE was engineered to test the null hypothesis 
that the stipend intervention provided no impact on school attendance relative to just the scholarship. This focus was chosen in discussions with NGF, because it was directly relevant to NGF's school promotion efforts. The scholarship portion of SIPE was identical to their Sponsored Education Program, or SEP, and this null hypothesis was equivalent to asserting that schooling outcomes would not be improved by providing additional financial support for earnings that would be foregone by attending school rather than working full-time. The sample size of 220 per treatment group was chosen to test the null hypothesis separately by gender, by age group, and by carpet establishment size.

The study size was chosen to be able to detect differences in school attendance between the scholarship and stipend treatments using a simple comparison of means in the yearend data. However, our interests are broader than school attendance alone. We consider outcomes related to school performance, completion, and child labor. For most outcomes ex-ante, we expected our sample size to be underpowered without additional controls. Moreover, the information available at the study design stage overstated the lack of schooling in the subject pool so that even school attendance differences are underpowered without controls.

Hence, we use a regression approach throughout our analysis. Because the randomization appears to have achieved balance (Table 3), these controls function to reduce variance and improve statistical power only. Specifically, we estimate:

$$
y_{i j k t}=\beta A_{i 0}+b_{0}+b_{1} S c_{i}+b_{2} S t_{i}+\alpha Y_{i j k 0}+\pi_{i j k 0}+\varepsilon_{i j k t}
$$

where $y_{i j k t}$ is outcome $y$ for child $i$ in family $j$ associated with establishment $k$ observed at time $t$. $S c$ is an indicator that child $i$ was assigned to the scholarship treatment, $S t$ is an indicator that child $i$ was assigned to the stipend treatment. All subjects who were offered the opportunity to participate in the scholarship or stipend treatments chose to participate, so there are no issues of take-up associated with interpreting the coefficients on these random assignment variables. $A$ is a vector of age fixed effects, a gender effect, and age*gender effects. $Y_{i j k 0}$ is a vector of the outcome variables observed at baseline. Its inclusion means that we identify the impact of the treatments based on changes in $y$ between the baseline period and either the midyear, yearend, or post period. SIPE randomization was conducted after stratifying the population into age group $\times$ gender $\times$ establishment size cells. $\pi$ is a vector of fixed effects denoting the subject's stratum used in randomization. $\varepsilon_{i j k t}$ is a mean zero error term. We cluster standard errors by establishment throughout 9 We think there is apt to be important clustering of time allocation decisions at

\footnotetext{
${ }^{9}$ The empirical approach stipulated in an analysis plan submitted to ICF before the availability of the midterm data or schooling records (available from authors upon request) was identical to what we use here with regards to the included controls, the functional form of these controls, and the clustering of the residuals. The only difference in specification is that the ex-ante analysis plan specified the scholarship dummy to be one for both the scholarship and stipend treatments so that the coefficient on the stipend indicator directly tested differences between the scholarship and the stipend. This difference in specification is only relevant for the presentation of results and is not substantive.
} 
the establishment level, because subjects are grouped together by establishment. 59 percent of subjects live inside the establishment, but the other 41 percent of subjects typically live proximate to the establishment where their caregiver works.

All results tables follow a similar structure. For each outcome of interest, we report the mean of the outcome for the control population and its standard deviation in column 1 . In column 2, we report $b_{1}$ and its standard error. This tests the null that outcome $y$ does not differ with the scholarship group compared to the control. Ex-ante, we expected modest effects of the scholarship, and we do not believe that our sample size is sufficient to detect effects of the scholarship in general even with the control function approach specified above. In column 3 , we report $b_{2}$ and its standard error. This tests the null that outcome $y$ does not differ with the stipend group compared to the control. In column 4, we report the difference between the two treatment groups $\left(b_{2}-b_{1}\right)$ and the F-Statistic associated with the null that the difference is zero. We report findings for the pooled sample and bifurcated by gender 10 Random assignment was conducted at the individual level, so spillovers are a distinct possibility and discussed in section $4 . b_{1}$ and $b_{2}$ are both identified net of any spillovers.

With two-thirds of subjects as migrants, attrition was an ex-ante concern in this study, and substantial resources were devoted to tracking subjects in every round except for the midyear survey 11 The survey instruments implemented by New ERA contained a great deal of information aimed to assist us in tracking study subjects. Out of the original 660 study subjects identified in February 2010, 655 were interviewed in the yearend survey in May 2011 and 650 participated in the followup survey in August of 2012 ${ }^{12}$ We regard this 98.5 percent retention rate as an achievement in a migrant population. Table 5 tabulates attrition by treatment group and data source. Attrition is uncorrelated with treatment status.

\section{$3 \quad$ Main Findings}

\subsection{Schooling}

School attendance appears to have been positively impacted by both the stipend treatment and the scholarship treatment while support lasted. Because scholarship funds were largely exhausted at the start of the

\footnotetext{
${ }^{10}$ While the design would allow bifurcation by age group and establishment size, we do not present those results herein. Establishment size differences were almost never substantive, and we do not think the value-added to the present discussion of the age group differences was sufficient to justify their inclusion.

${ }^{11}$ While the project funder wanted a midyear survey for their own goals, an important part of the midyear survey was to collect tracking information on individuals before the October holidays where many families go home. Hence, we did not feel it was worth the resources at that time to track down families that had already migrated.

${ }^{12}$ We have some information on 7 of the 10 missing children. One child died. One child is from a family who is in hiding because of unpaid debts. Two children came from a closed factory. Their location was unknown by any of their provided contacts or former classmates. Three children (all unrelated) are in an unknown location after their mothers left their fathers (all abroad) for another man.
} 
school year, we see smaller overall effects of the scholarship on schooling when compared to the scholarship.

The impact of the scholarship on having attended school during the year of support and the attendance rate overall is evident in Table 6. 92 percent of control subjects attended school during the year support (down 6 percentage points compared to the school year before support). The scholarship increased this by a statistically insignificant 2.3 percentage points compared to the control. The stipend increased this by a statistically significant 4.9 percentage points. The school attendance rate is the number of days the subject attended school divided by the number of days that the subject's school was open for teaching (defined using NGF's administrative records). Control subjects attended school 4 out of every 5 days the schools was open for teaching. Stipend subjects attended school more than scholarship or control, a total of 91 percent of days.

The month by month impact of the treatments on attendance rates during the year of support is pictured in Figure 1. The difference between the stipend treatment and control treatment is statistically significant in every month. The difference between the scholarship treatment and control is not statistically significant in any month. The difference between the stipend subjects and the control or scholarship populations is greatest in month 7 . This is a month with two important festivals where many families migrate back to their place of origin in rural Nepal. We specifically timed the midterm survey before this festival season in order to make sure that we had the most recently available information to track mobile subjects. We find that the stipend significantly reduced the proportion of days missed by subjects during the festival season.

Figure 1 combines the extensive margin of attendance (attend school at all in the month) with the intensive margin (number of days attended conditional on attendance). By combining the two, the figure mixes something the scholarship treatment can affect (the extensive margin - it makes school free until funds are exhausted) with something it does not affect (the intensive margin - the cost of attending school on any given day doesn't change once the extensive margin costs have been paid). Figure 2 pictures the impact of both treatments on the extensive margin of attendance for the month. We find treatment effects are very similar on the extensive margin between the two treatments at the start of the year, but the impact of the scholarship treatment starts to fade and the gap between the scholarship and the stipend treatment grows throughout the year. In fact, the impact of the scholarship on the extensive margin of schooling differs significantly from the control in the first two months of the year. Figure 3 contains the impact of each treatment by month conditional on attending school. As we would expect, here we see no effect of the scholarship on attendance compared to the control. Given that the stipend pays for attendance, we would expect to see large intensive margin effects for the stipend treatment, and we see such, especially in month 7. The scholarship reduces the cost of attendance on the extensive margin without any impact on the intensive margin. Hence, the two treatments impact attendance along the lines of "You get what you pay for." 
The additional attendance in the stipend treatment is associated with increased probability of taking final exams and scoring better on the in-school final exams (Table 6). The impacts on the probability of taking the test are large, a nearly 10 percent increase in the probability of taking the test compared to the control or the scholarship group. The probability that individual failed the school year was reduced by both treatments. The increase in test scores is positive for both treatments, but slightly larger for the stipend treatment. The fact that the two treatments are associated with a reduced failure rate implies that the extra test score improvements for the stipend population are not at the margin of passing.

We cannot reject the null of no effect of either treatment on schooling past the year of support. These findings are in Table 7. In the year after support, we do not observe a substantive difference in enrollment between the treatment groups. The scholarship and stipend groups are slightly less likely to pass their grade of enrollment in the year after support (although these negative coefficients are not statistically significant) ${ }^{13}$ Enrollment falls off between one year past support and two years past support, and we cannot reject a null of no difference in school enrollment for the year or attendance in the month of the follow-up survey (two academic years removed from the supported year) across treatment groups. Although stipend subjects were 44 percent less likely to fail school during the year of support (Table 6), we are not able to reject the null hypothesis that they have no higher schooling attainment after one year and a half. Hence, there do not appear to be lasting effects of the treatment beyond the period of support for schooling.

During the year of support, the effects of the stipend are largest for girls. Table 8 bifurcates the sample by gender. It is apparent that most of the statistically significant effects of the stipend in Table 6 came from the response of girls to the stipend (although boys show significantly higher attendance rates as well). The impact of the stipend is especially large for the failure rate of girls (reducing the probability of failing by 66 percent). As with the pooled sample, we cannot reject the null hypothesis that the impact of the stipend on schooling for girls lasted only during the year of support.

\subsection{Child Labor}

The purpose of this intervention, from the funder's perspective, was to stop children from weaving. Weaving is considered a hazardous form of child labor because of its association with long-term spinal injuries, arthritis, respiratory ailments, and eyesight damage as well as the prevalence of forced and bonded labor in the sector. We find that the stipend intervention substantively reduced weaving among treated girls during the period of support.

At baseline, 9.5 percent of control children were involved in weaving. 11.4 percent of control children

\footnotetext{
${ }^{13}$ Passing in Table 7 is based on caregiver responses whereas passing in Table 6 is from school administrative records. We suspect the higher pass rate in the control sample in the year after response owes to this difference in respondent.
} 
participated in weaving at some point during the year of support. 12.9 percent of control children participated in weaving 16 months past the year of support. It may seem surprising that an intervention aimed at preventing a hazardous form of child labor would deal with subjects whose probability of entering into the activity are far from 1 during the period of support. However, this is not at all unusual for education interventions aimed at deterring entry into hazardous child labor 14 These illegal activities are rare, so it would be surprising if we were were able to identify a subject pool with a transition probability close to 1 . Given that the probability a child works in any form for pay in Kathmandu is 3.8 percent, we think it is appropriate to view children with counterfactual probabilities of being involved in a hazardous form of child labor of more than 10 percent as children who are vulnerable to hazardous child labor.

Table 9 contains the impact of the scholarship and stipend treatments on weaving in the pooled sample. We can measure child involvement in weaving at 4 points in time: in the 7 days before the interview in the yearend survey, in the 12 months before the yearend survey (including the 7 days before the interview and including most of the year of support), in the 30 days before the follow-up survey, and in the 12 months before the followup survey (which would include the 30 days). We begin the table with the 7 days before the interview measure, because we also have hours worked data to match that recall period. 7.3 percent of control subjects weaved in the 7 days prior to the year end survey. On average, those that weaved did so for 30 hours over the previous 7 days. It is useful to note that this is not total time working, only time spent weaving. The stipend is associated with a 4.3 percentage point or 59 percent reduction in weaving. The decline in hours worked associated with the stipend is greater than would be predicted by the decline in participation alone. The decline in participation in the stipend population, using the controls hours as a counterfactual, implies that the coefficient on the stipend treatment in row 2 should be -1.253 instead of the observed -1.497. The larger observed treatment effect might reflect a treatment effect on the intensity of weaving, or it might reveal that those whose weaving is most influenced by the stipend are those who weave more time-intensively absent the treatment.

The 7 days prior to the yearend survey does not include the period where conditionality was enforced for the stipend. However, we think the reduction in weaving in the 7 days prior to the yearend survey may reflect the reduced labor supply during the period of support. The mode carpet size being manufactured in Kathmandu at the time of our study was 8 foot x 10 foot with 100 knots per square inch. Carpets are knotted in teams who work in a line. The consistency of knotting in the product requires that the team is held constant throughout the manufacturing process. Thus, it would not be unusual for a team to spend more than a month dedicated to an $8 \times 10$ carpet during normal work periods. The yearend survey was

\footnotetext{
${ }^{14}$ The U.S. Department of Labor's Office of Child Labor, Forced Labor, and Human Trafficking regular publishes research on its website that report on interventions aim at populations vulnerable to hazardous child labor.
} 
conducted around the Nepali New Year's celebrations. It would not be surprising to learn that carpets being manufactured at the time of our yearend survey were started when conditionality was enforced in the stipend intervention, and the impact of the stipend on weaving participation in the past 7 days during the yearend survey may reflect a combination of the impact of the stipend and whatever decisions were being made after the end of support.

We prefer the measure of child weaving the 12 months prior to the yearend survey as our measure of the impact of the stipend treatment on weaving during the period of support. The stipend reduces the probability the child was engaged in weaving during the year of support by 5.5 percentage points or 48 percent. The scholarship does not appear to be associated with a reduction in weaving, and we can reject the null of no difference between the scholarship and stipend treatments at 10 percent. 16 months past the end of support, we cannot reject the null of no impact of either treatment on child engagement in weaving.

The reduction in child labor is concentrated in girls. Results bifurcated by gender are in Table 10 . Boys are less likely to be involved in weaving compared to girls (6 percent vs. 16 percent), and even when they participate in weaving, boys do so for fewer hours on average than participating girls. Hence, we do not find it surprising that we observe larger effects of the stipend among girls. Girls' involvement in weaving in the year of support declines by 10 percentage points or 64 percent. Girls are more likely to weave at follow-up compared to the year of support, 19 percent compared to 16 percent. However, we cannot reject the null of no effect of either intervention at follow-up for boys or girls.

\section{Discussion}

Both the scholarship and stipend treatments lasted one academic year. Recipients were told in advance that support would last only one year and that no future support was anticipated. A simple, static labor supply model predicts the "You get what you pay for" response to the scholarship and stipend treatments we observe.

In its simplest presentation, the classical static labor supply model has a single agent with preferences over consumption of a composite good $c$ and schooling $s . u(c, s)$ is the utility representation of these preferences. The child time endowment $T$ is allocated between schooling $s$ and labor $l: T=s+l$. The price of the composite good is normalized to 1 . Schooling is costly at price $p$. The agent is endowed with non-child labor income $Y$. Child labor earns a wage $w$. Hence the budget constraint is $c+p s=w l+Y$. Plugging in the time constraint into the budget constraint, we get the full income constraint: $c+(w+p) s=w T+Y$.

Figure 4 illustrates the impact of the scholarship on schooling and work decisions. While in effect, the price of schooling declines, inducing the agent to consume more schooling. This is pictured as a shift 
from equilibrium $a$ to equilibrium $b$. Consumption need not decline, but it could depending on preferences. Importantly, once the scholarship funds are exhausted, the full income constraint returns to its original level, and equilibrium $a$ returns. Hence, the impact of the scholarship should only persist so long as scholarship funds are available as we observe in section 3.1.

Figure 5 illustrates the impact of the stipend intervention in the static labor supply model. We have the effect of the scholarship, plus the additional discontinuity in the full income constraint created by the school attendance requirement of the stipend. When the program is in effect, subjects move from equilibrium $a$ to $c$. However, when the project ends, we return to equilibrium $a$. The reduction in child labor (which is modeled as the alternative to time in school) and increase in schooling only lasts as long as support.

This discussion highlights that the stipend includes both the income effect of the change in the price in schooling and the effect of the additional income that comes with the stipend. We are surprised that a dynamic model does not better explain our results. Ex-ante, our expectation was that forward-looking households would exhibit permanent income behavior, treat the one year of support as a transitory income shock, and save a significant portion of the transfer, at least for the stipend treatment. The stipend was paid in-kind, but we did not expect the in-kind transfer to be binding with respect to rice and pulse consumption. Hence, there would be ample means to save the stipend.

Additional savings does not appear to have materialized. Table 11 documents the impact of the transfers on household savings and spending. 17 percent of households report some savings, and the stipend recipients do not appear more likely to save. In fact, stipend recipients report saving less. The stipend appears to have been spent. The stipend and scholarships appear to be associated with similar increases in educational expenses. The amount of increase in education spending is roughly of the magnitude that would be predicted by the scholarship's impact on schooling and the larger magnitude of the stipend (not statistically different from the scholarship) is in-line with the stipend's larger impact on schooling. The increase in food expenses with the stipend implies that 73 percent of the stipend went towards increased food expenditures ${ }^{15}$ This does not seem to be far off from what we would expect for the slope of an Engel curve in a poor population like our subject pool, but we cannot rule out some type of non-fungibility in the household budget. Total expenses increase with the stipend such that 85 percent of the transfers seems to have been translated directly into new spending ${ }^{16}$ This is far off the marginal propensity to consume transitory income that the permanent-income hypothesis would suggest.

What happens to the remaining 15 percent of the transfer that is not accounted for by expenditures?

\footnotetext{
${ }^{15}$ There are on average 1.2 stipend recipients per family with at least one child winning a stipend. The increased food expenditure associated with the stipend in Table 11 is NPR 877 per month.

${ }^{16}$ For stipend award winning families, there are on average 1.2 stipend recipients (who also receive the scholarship treatment) and 0.3 scholarship recipients. This implies a total increase in resources on average per month of NPR 1694 for stipend families. The results for total expenditures in Table 11 imply additional monthly expenditures of NPR 1433 on average.
} 
We have already documented a decline in child engagement in weaving associated with the transfer. In expectation, this reduction in child weaving results in foregone earnings that are greater than the amount of the transfer for an individual child. The stipend transfer is NPR 1,000 per month, and the average monthly wage of a full-time weaver under 20 at the time of our study is NPR 3,078 per month. A 6 percent decline in weaving with 1.2 recipients per household implies a NPR 222 decline in income. This is 85 percent of the difference between the increase in consumption observed in Table 11 and the increase in resources associated with the stipend treatment. There is also some evidence that the transfer was associated with a decline in adult labor supply. This is evident in the bottom row of the table. Average adult hours worked declines by 3.3 hours per week in stipend recipient households compared to control households. Overall, then, it appears the stipend was spent largely on food but also on reduced child and adult labor. There does not appear to be substantive permanent-income type smoothing behavior.

This observation that there appears to be a decline in adult labor supply raises the question of spillovers within household as there can be control and treated children within the same family. If there are important spillovers in time allocation, this would reduce our estimates of the effect of the stipend or scholarship treatment. To examine spillovers, we limit our sample to control subjects. We modify equation (1) to control for the number of subjects in the family (which is non-random), $N_{j}$. Conditional on $N_{j}$, the presence of a scholarship winner $S c W_{j}$ or a stipend winner $S t W_{j}$ in the family will be random. Hence, we estimate:

$$
y_{i j k t}=\beta A_{i 0}+b_{0}+\delta_{0} N_{j}+\delta_{1} S c W_{j}+\delta_{2} S t W_{j}+\alpha Y_{i j k 0}+\pi_{i j k 0}+e_{i j k t}
$$

where $\delta_{1}$ is how outcome $y$ differs for a control child when there is a scholarship winner in the family (compared to no scholarship winner), and $\delta_{2}$ is how outcome $y$ differs for a control child when there is a stipend winner in the family. Estimates of $\delta_{0}, \delta_{1}$, and $\delta_{2}$ are reported in Table 12 In general, the more eligible children in the family, the worse the schooling outcomes and the more prevalent weaving. $\delta_{0}$ is not causally identified, but the general pattern matches the NGF inspector priors that resource dilution is apt to be an important influence on time allocation. The presence of a scholarship or a stipend winner in a control child's family is associated with higher school attendance for the control child. Spillovers in school attendance have been documented in other contexts (e.g. Angelucci \& De Giorgi (2009), Bobonis \& Finan (2009)), and we cannot separately identify whether this increase in schooling attendance reflects resource transfers or peer effects. However, in the remaining 14 regressions in the table, we cannot reject the null of no spillover at 5 percent for any outcome. The clearest evidence of spillovers in labor supply from the stipend treatment come from the apparent reduction in hours worked among adults. 


\section{Conclusion}

Combating child labor through education promotion is at the center of anti-child labor policy aimed at ending the involvement of 115 million children worldwide in hazardous child labor. The USG is the largest funder of anti-child labor programs worldwide, and financial education support in USG-funded programs is required to be transitory by federal law. We evaluate the impact of an USG anti-child labor aimed at children vulnerable to child labor in the hand-made export-oriented carpet sector of Nepal. We evaluate the impact of a scholarship program designed to cover direct, out-of-pocket schooling expenses and a stipend program that included the scholarship plus an additional stipend conditional on school attendance in the previous month.

We have found small, positive effects of a scholarship program that covered out-of-pocket schooling expenses on whether subjects attended school at all at the start of the period of support. These treatment effects on schooling dissipate quickly such that we found no effects on school attendance for the year of support (although scholarship recipients were more likely to pass the school year). We found larger, substantive effects of the combined scholarship and stipend program that covered school expenses and provided a large stipend conditional on school attendance. The stipend treatment appeared to reduce child involvement in carpet weaving, a worst form of child labor in Nepal. However, after 16 months, we find no evidence of the program in schooling attendance, grade level, or child labor. These findings are inconsistent with the hypothesis underlying USG anti-child labor policy that transitory education interventions are an effective tool to combat child labor in the long run. Our findings suggest an impact on child labor and schooling during the period of support, but it decays quickly after support ends. You get what you pay for.

Our "You Get What You Pay For" findings are exactly what a classical static labor supply model would predict. The scholarship changes the relative price of consuming schooling until its funds are exhausted, then the original equilibrium returns. The stipend also changes the relative price of consuming schooling as well as shifting the budget constraint in a way that induces more consumption of schooling and less child labor until the incentive is removed. This classical model is rarely used in the child labor or schooling literatures at present. Our findings illustrate that this classical framework can be useful for understanding child labor even in a case of a worst form of child labor.

An interesting question is why does the classical static labor supply model do such a complete job of explaining the response to the program evaluated herein. In the present case, subjects knew that the support was transitory. We suspect that is not always the case in anti-child labor programs, but the implementing NGO went to great lengths to make sure that recipients knew the support was transitory. We expect poor families to save positive transitory income shocks. Families appear to spend 85 percent of the stipend. The 
balance does not appear to have been saved and may be accounted for with reduced labor supply by study subjects and their adult care-givers. We do not see permanent-income type behaviors in response to this transitory support. One possible explanation for the lack of smoothing is that the poor subjects could be facing a subsistence constraint (e.g. Dasgupta \& Ray (1986)). Eating could be the highest marginal return available to recipient households. If this were the case, we are surprised we do not see more children involved in child labor. Work in the carpet sector appears to be readily available to subjects; we frequently heard complaints from employers that they could not find workers. If our subject families were suffering from not having enough to eat to subsist, we would expect to see a lot more child labor than we do. Liquidity constraints are a possibility. Other studies have found liquidity constraints to be an important influence on child labor and schooling (e.g. Edmonds (2006)). However, ordinarily we think of liquidity constraints as limiting an agent's ability to borrow against future income rather than to find a way to save current income. Financial access among migrant workers in the Kathmandu Valley is not perfect, but 17 percent of control subjects are in families with positive savings. We do not think that this is a setting where agents face physical constraints on their ability to save, but there is nothing herein to rule out the possibility of physical liquidity constraints preventing families from transferring transitory income forward. The explanation for why a simple, static labor supply model can so completely capture the response to the schooling incentives considered herein is an interesting question for future study, but we believe our findings should revive the utility of this model in future discussions of child labor and schooling policy.

\section{Works Cited}

\section{References}

Angelucci, M. \& De Giorgi, G. (2009), 'Indirect effects of an aid program: How do cash transfers affect ineligibles' consumption?', American Economic Review pp. 486-508.

Attanasio, O., Fitzsimons, E., Gomez, A., Gutierrez, M. I., Meghir, C. \& Mesnard, A. (2010), 'Children's schooling and work in the presence of a conditional cash transfer program in rural colombia', Economic Development and Cultural Change 58(2), 181-210.

Baland, J.-M. \& Robinson, J. A. (2000), 'Is child labor inefficient?', Journal of Political Economy 108(4), 663-679.

Barrera-Osorio, F., Bertrand, M., Linden, L. L. \& Perez-Calle, F. (2011), 'Improving the design of conditional 
transfer programs: Evidence from a randomized education experiment in colombia', American Economic Journal: Applied Economics 3(2), 167-195.

Basu, K. \& Van, P. H. (1998), 'The economics of child labor', American Economic Review pp. 412-427.

Beegle, K., Dehejia, R. H. \& Gatti, R. (2006), 'Child labor and agricultural shocks', Journal of Development Economics 81(1), 80-96.

Behrman, J. R., Parker, S. W. \& Todd, P. E. (2011), 'Do conditional cash transfers for schooling generate lasting benefits? a five-year followup of progresa/oportunidades', Journal of Human Resources 46(1), 93122.

Bobonis, G. J. \& Finan, F. (2009), 'Neighborhood peer effects in secondary school enrollment decisions', The Review of Economics and Statistics 91(4), 695-716.

Bursztyn, L. \& Coffman, L. C. (2012), 'The schooling decision: Family preferences, intergenerational conflict, and moral hazard in the brazilian favelas', Journal of Political Economy 120(3), 359-397.

Cogneau, D. \& Jedwab, R. (2012), 'Commodity price shocks and child outcomes: The 1990 cocoa crisis in côte d'ivoire', Economic Development and Cultural Change 60(3), 507-534.

Dammert, A. C. (2008), 'Child labor and schooling response to changes in coca production in rural peru', Journal of Development Economics 86(1), 164-180.

Dammert, A. C. (2009), 'Heterogeneous impacts of conditional cash transfers: evidence from nicaragua', Economic Development and Cultural Change 58(1), 53-83.

Dasgupta, P. \& Ray, D. (1986), 'Inequality as a determinant of malnutrition and unemployment: theory', The Economic Journal 96(384), 1011-1034.

De Janvry, A., Finan, F., Sadoulet, E. \& Vakis, R. (2006), 'Can conditional cash transfer programs serve as safety nets in keeping children at school and from working when exposed to shocks?', Journal of Development Economics 79(2), 349-373.

Dessy, S. E. \& Pallage, S. (2005), 'A theory of the worst forms of child labour*', The Economic Journal 115(500), 68-87.

Duflo, E. (2001), 'Schooling and labor market consequences of school construction in indonesia: Evidence from an unusual policy experiment', The American Economic Review 91(4), 795-813. 
Duryea, S., Lam, D. \& Levison, D. (2007), 'Effects of economic shocks on children's employment and schooling in brazil', Journal of Development Economics 84(1), 188-214.

Duryea, S. \& Morrison, A. (2004), 'The effect of conditional transfers on school performance and child labor: Evidence from an ex-post impact evaluation in costa rica'.

Edmonds, E. V. (2006), 'Child labor and schooling responses to anticipated income in south africa', Journal of Development Economics 81(2), 386-414.

Edmonds, E. V. \& Pavcnik, N. (2005), 'The effect of trade liberalization on child labor', Journal of International Economics 65(2), 401-419.

Edmonds, E. V., Pavcnik, N. \& Topalova, P. (2010), 'Trade adjustment and human capital investments: Evidence from indian tariff reform', American Economic Journal: Applied Economics 2(4), 42-75.

Edmonds, E. V. \& Schady, N. (2012), 'Poverty alleviation and child labor', American Economic Journal: Economic Policy 4(4), 100-124.

Galiani, S. \& McEwan, P. J. (2011), 'The heterogeneous impact of conditional cash transfers', Wellesley, $M A$.

ICF (2012), Children working in the carpet industry of nepal: Prevalence and conditions, Technical report, ICF International, http://www.dol.gov/ilab/programs/ocft/pdf/PrevalenceConditionsStudy-Nepal.pdf.

International Labour Organization (2010), 'Accelerating action against child labour'.

Jacoby, H. G. \& Skoufias, E. (1997), 'Risk, financial markets, and human capital in a developing country', The Review of Economic Studies 64(3), 311-335.

Jensen, R. (2010), 'The (perceived) returns to education and the demand for schooling', The Quarterly Journal of Economics 125(2), 515-548.

Maluccio, J. \& Flores, R. (2005), Impact evaluation of a conditional cash transfer program: The Nicaraguan Red de Protecciòn Social, Intl Food Policy Res Inst.

Ranjan, P. (2001), 'Credit constraints and the phenomenon of child labor', Journal of Development Economics 64(1), 81-102.

Ravallion, M. \& Wodon, Q. (2000), 'Does child labour displace schooling? evidence on behavioural responses to an enrollment subsidy', The Economic Journal 110(462), 158-175. 
Rogers, C. A. \& Swinnerton, K. A. (2008), 'A theory of exploitative child labor', Oxford Economic Papers 60(1), 20-41.

Schady, N. R. \& Araujo, M. C. (2006), Cash transfers, conditions, school enrollment, and child work: Evidence from a randomized experiment in Ecuador, Vol. 3930, World Bank Publications.

Schultz, T. W. (1960), 'Capital formation by education', Journal of Political Economy 68(6), 571-583.

\section{Figures and Tables}

Figure 1: Treatment Effects on School attendance by Month during year of Support

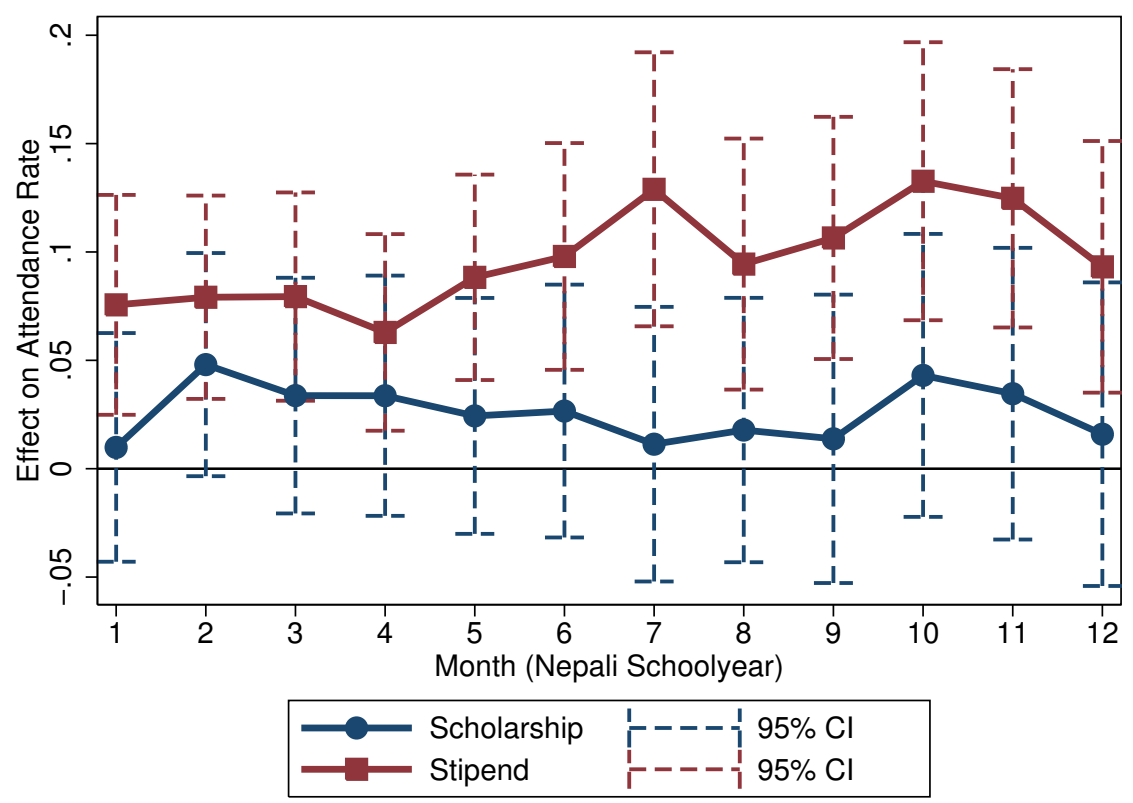


Figure 2: Treatment Effects on whether attends school in a month

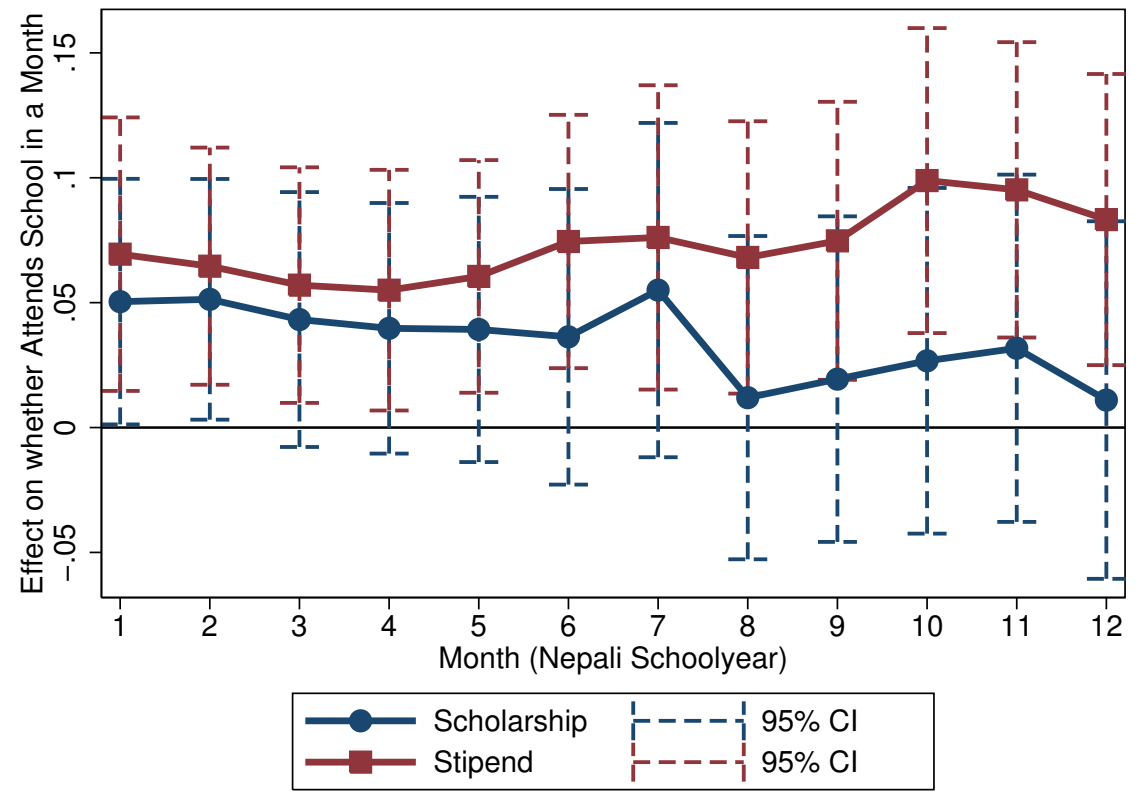

Figure 3: Treatment Effects on School Attendance conditional on any attendance in month

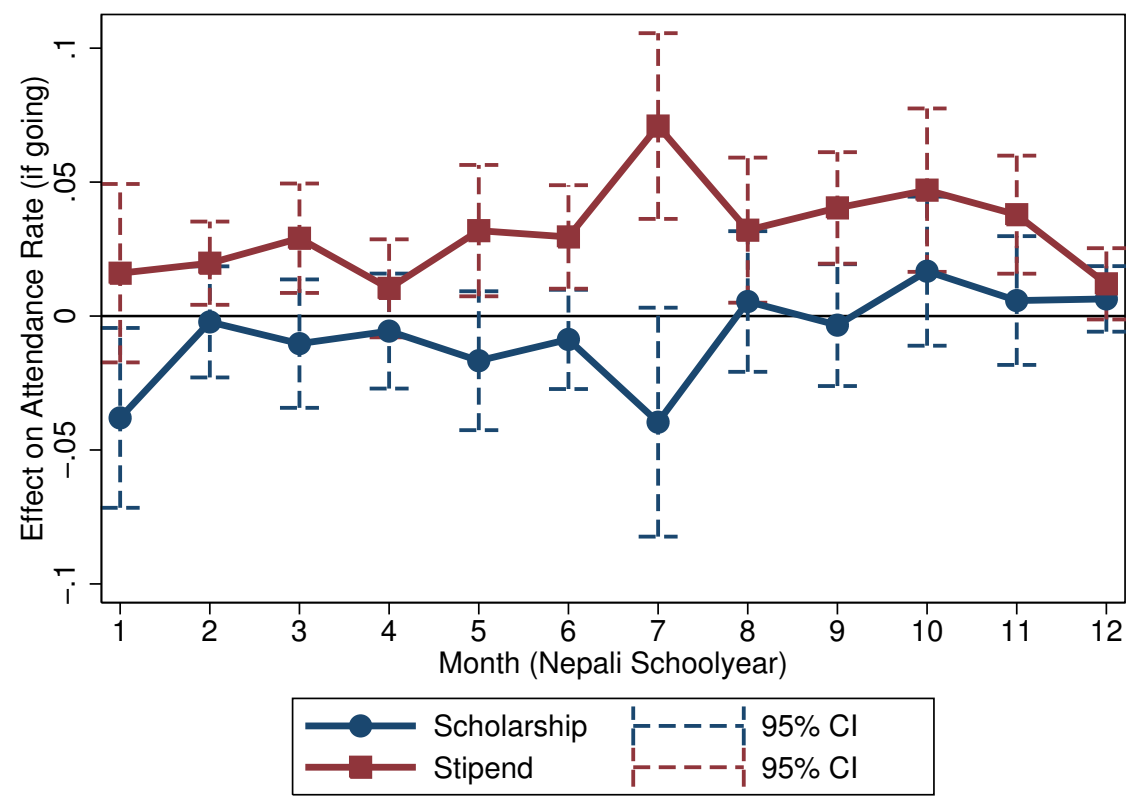


Figure 4: Effect of Scholarship on consumption, labor and schooling

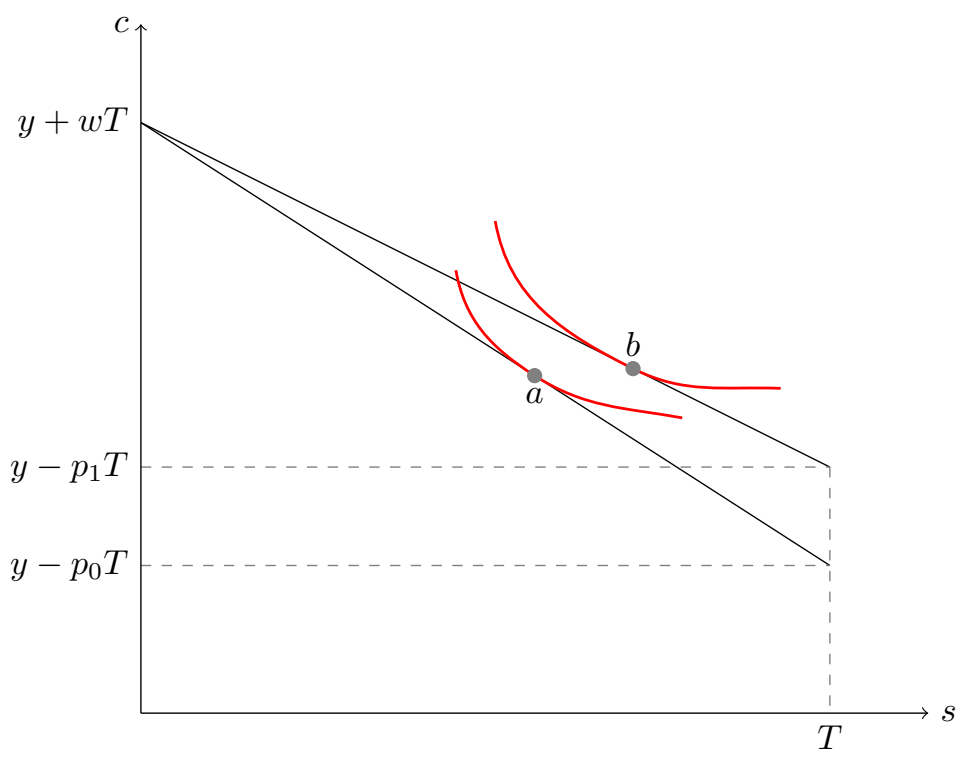

Figure 5: Effect of Stipend on consumption, labor and schooling

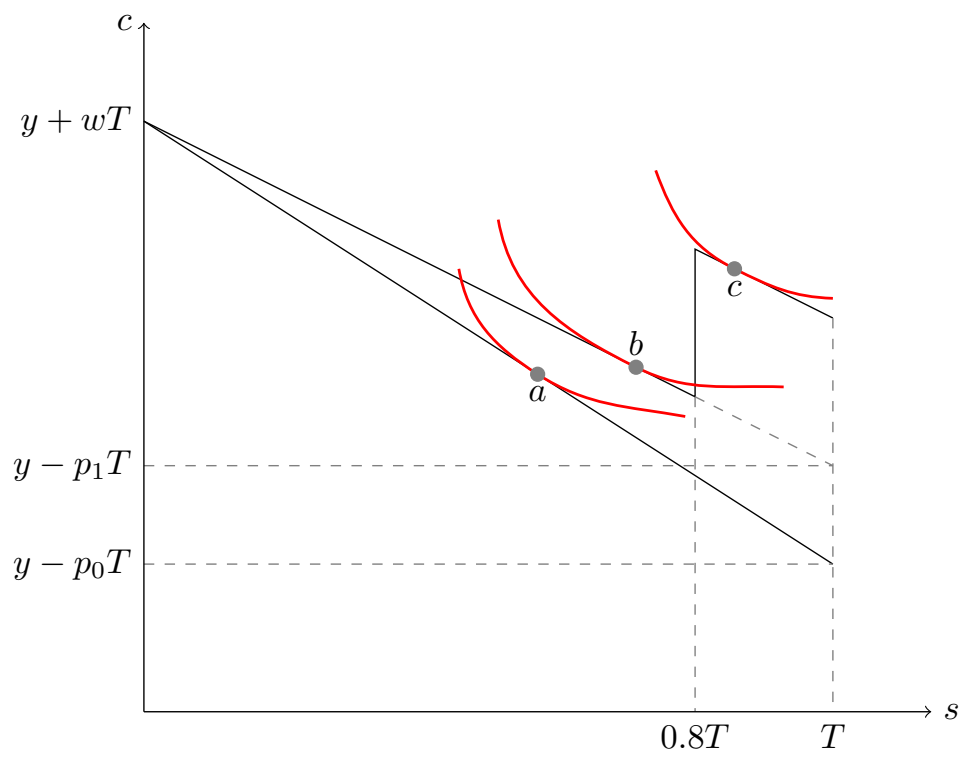


Table 1: Eligibility Criteria and SIPE Study Population

\begin{tabular}{lc} 
Criteria & $\begin{array}{c}\text { Number of Subjects } \\
\text { Matching Criteria }\end{array}$ \\
\hline Family Size & 255 \\
Low income, no housing & 234 \\
Low income, housing provided & 396 \\
Siblings, 1 or fewer in school & 135 \\
Siblings, Dropout & 52 \\
\hline Total & 660 \\
\hline \hline Source: Authors' calculations from NGF Eligibility Survey (2010).
\end{tabular}


Table 2: SIPE Study Population

\begin{tabular}{|c|c|c|c|c|c|c|c|c|c|c|}
\hline & \multicolumn{2}{|c|}{ Study Subjects } & \multicolumn{2}{|c|}{ National } & \multicolumn{2}{|c|}{ Poor (National) } & \multicolumn{2}{|c|}{ Kathmandu Valley } & \multicolumn{2}{|c|}{ Poor (Valley) } \\
\hline & mean & sd & mean & $\mathrm{sd}$ & mean & sd & mean & $\mathrm{sd}$ & mean & $\mathrm{sd}$ \\
\hline \multicolumn{11}{|l|}{ Demographics } \\
\hline Age & 12.274 & 6.158 & 12.918 & 2.012 & 12.685 & 2.026 & 13.314 & 1.978 & 13.253 & 1.955 \\
\hline Female & 0.541 & 0.499 & 0.499 & 0.500 & 0.520 & 0.500 & 0.512 & 0.500 & 0.397 & 0.494 \\
\hline \multicolumn{11}{|l|}{ Caste/Ethnicity } \\
\hline Brahman/Chhetri & 0.070 & 0.255 & 0.300 & 0.458 & 0.227 & 0.419 & 0.325 & 0.469 & 0.110 & 0.316 \\
\hline Newar & 0.053 & 0.224 & 0.053 & 0.223 & 0.022 & 0.146 & 0.347 & 0.476 & 0.329 & 0.474 \\
\hline Tamang/Magar & 0.658 & 0.475 & 0.129 & 0.335 & 0.153 & 0.360 & 0.179 & 0.383 & 0.371 & 0.488 \\
\hline Dalits & 0.020 & 0.139 & 0.137 & 0.344 & 0.226 & 0.418 & 0.029 & 0.167 & 0.111 & 0.317 \\
\hline Others & 0.200 & 0.400 & 0.381 & 0.486 & 0.373 & 0.484 & 0.121 & 0.326 & 0.079 & 0.273 \\
\hline \multicolumn{11}{|l|}{ Religion } \\
\hline Hindu & 0.439 & 0.497 & 0.831 & 0.375 & 0.821 & 0.384 & 0.784 & 0.412 & 0.792 & 0.410 \\
\hline Buddhist & 0.471 & 0.500 & 0.075 & 0.263 & 0.085 & 0.279 & 0.165 & 0.371 & 0.192 & 0.398 \\
\hline Others & 0.089 & 0.286 & 0.094 & 0.292 & 0.094 & 0.292 & 0.052 & 0.221 & 0.016 & 0.126 \\
\hline \multicolumn{11}{|l|}{ Parent Information } \\
\hline Live with both parents & 0.641 & 0.480 & 0.664 & 0.472 & 0.730 & 0.444 & 0.715 & 0.452 & 0.729 & 0.449 \\
\hline Mother present in $\mathrm{HH}$ & 0.965 & 0.184 & 0.897 & 0.305 & 0.919 & 0.273 & 0.837 & 0.369 & 0.792 & 0.410 \\
\hline Mother literate (if present) & 0.126 & 0.332 & 0.270 & 0.444 & 0.112 & 0.315 & 0.564 & 0.496 & 0.297 & 0.462 \\
\hline Yrs of Schooling (mom) & 0.559 & 1.553 & 1.485 & 3.093 & 0.360 & 1.371 & 4.499 & 5.023 & 0.843 & 2.072 \\
\hline Father present in $\mathrm{HH}$ & 0.676 & 0.468 & 0.693 & 0.461 & 0.762 & 0.426 & 0.758 & 0.429 & 0.874 & 0.335 \\
\hline Father literate (if present) & 0.590 & 0.492 & 0.615 & 0.487 & 0.470 & 0.499 & 0.888 & 0.315 & 0.653 & 0.481 \\
\hline Yrs of Schooling (dad) & 2.446 & 2.521 & 4.105 & 4.329 & 2.513 & 3.477 & 7.916 & 4.724 & 3.988 & 4.151 \\
\hline \multicolumn{11}{|l|}{ Migration, Schooling and Work } \\
\hline Born elsewhere & 0.655 & 0.476 & 0.119 & 0.324 & 0.057 & 0.232 & 0.298 & 0.458 & 0.157 & 0.368 \\
\hline Currently attending school & 0.974 & 0.159 & 0.893 & 0.309 & 0.833 & 0.373 & 0.943 & 0.232 & 0.889 & 0.317 \\
\hline Completed Years of Schooling & 3.932 & 2.256 & 4.727 & 2.663 & 3.662 & 2.440 & 6.180 & 2.425 & 5.285 & 2.600 \\
\hline Wage work in past 7 days & 0.098 & 0.298 & 0.079 & 0.271 & 0.113 & 0.317 & 0.038 & 0.192 & 0.079 & 0.272 \\
\hline
\end{tabular}

Source: Authors' calculations from NE-B and NLSS-III. Study subjects refers to the 660 children who were the subject of this evaluation. The rest of the columns refer to children aged 10-16 in the third Nepal Living Standards Survey (NLSS-III) 2010/11. NLSS-III has 5,275 children in the national sample and 527 children in the Kathmandu sample. Poverty classification done based on consumption-based poverty measure of CBS 2011. The SIPE study did not have information on parental literacy when a parent was not present in either sample 
Table 3: Validity of Randomization

\begin{tabular}{|c|c|c|c|c|}
\hline & $\begin{array}{l}\text { Control } \\
\text { mean/(sd) } \\
(1)\end{array}$ & $\begin{array}{l}\text { Scholarship } \\
\text {-Control } \\
\text { b/(se) } \\
(2)\end{array}$ & $\begin{array}{l}\text { Stipend } \\
\text {-Control } \\
\text { b/(se) } \\
(3)\end{array}$ & $\begin{array}{l}\text { Stipend } \\
\text {-Scholarship } \\
\text { b/(F) } \\
\text { (4) }\end{array}$ \\
\hline Age & $\begin{array}{l}11.859 \\
(2.017)\end{array}$ & $\begin{array}{l}0.055 \\
(0.199)\end{array}$ & $\begin{array}{l}0.014 \\
(0.199)\end{array}$ & $\begin{array}{l}-0.041 \\
(0.042)\end{array}$ \\
\hline Female & $\begin{array}{l}0.541 \\
(0.499)\end{array}$ & $\begin{array}{l}-0.014 \\
(0.048)\end{array}$ & $\begin{array}{l}0.014 \\
(0.048)\end{array}$ & $\begin{array}{l}0.027 \\
(0.328)\end{array}$ \\
\hline \# employees in establishment & $\begin{array}{l}41.182 \\
(25.342)\end{array}$ & $\begin{array}{l}0.518 \\
(2.542)\end{array}$ & $\begin{array}{l}-0.041 \\
(2.542)\end{array}$ & $\begin{array}{l}-0.559 \\
(0.048)\end{array}$ \\
\hline Live inside establishment premise & $\begin{array}{l}0.591 \\
(0.493)\end{array}$ & $\begin{array}{l}0.000 \\
(0.047)\end{array}$ & $\begin{array}{l}-0.005 \\
(0.047)\end{array}$ & $\begin{array}{l}-0.005 \\
(0.009)\end{array}$ \\
\hline Live with both parents & $\begin{array}{l}0.655 \\
(0.477)\end{array}$ & $\begin{array}{l}-0.018 \\
(0.046)\end{array}$ & $\begin{array}{l}-0.023 \\
(0.046)\end{array}$ & $\begin{array}{l}-0.005 \\
(0.010)\end{array}$ \\
\hline Born elsewhere & $\begin{array}{l}0.659 \\
(0.475)\end{array}$ & $\begin{array}{l}0.027 \\
(0.045)\end{array}$ & $\begin{array}{l}-0.041 \\
(0.045)\end{array}$ & $\begin{array}{l}-0.068 \\
(2.259)\end{array}$ \\
\hline Household size & $\begin{array}{l}4.586 \\
(1.299)\end{array}$ & $\begin{array}{l}0.077 \\
(0.126)\end{array}$ & $\begin{array}{l}-0.023 \\
(0.126)\end{array}$ & $\begin{array}{l}-0.100 \\
(0.629)\end{array}$ \\
\hline Completed education & $\begin{array}{l}4.018 \\
(2.208)\end{array}$ & $\begin{array}{l}-0.186 \\
(0.215)\end{array}$ & $\begin{array}{l}-0.073 \\
(0.215)\end{array}$ & $\begin{array}{l}0.114 \\
(0.279)\end{array}$ \\
\hline Currently going to school & $\begin{array}{l}0.977 \\
(0.149)\end{array}$ & $\begin{array}{l}-0.005 \\
(0.015)\end{array}$ & $\begin{array}{l}0.000 \\
(0.015)\end{array}$ & $\begin{array}{l}0.005 \\
(0.096)\end{array}$ \\
\hline Child involved in weaving carpets & $\begin{array}{l}0.095 \\
(0.295)\end{array}$ & $\begin{array}{l}-0.027 \\
(0.028)\end{array}$ & $\begin{array}{l}0.018 \\
(0.028)\end{array}$ & $\begin{array}{l}0.045 \\
(2.708)\end{array}$ \\
\hline Educational expenditure (000) & $\begin{array}{l}13.325 \\
(11.241)\end{array}$ & $\begin{array}{l}-0.478 \\
(1.089)\end{array}$ & $\begin{array}{l}0.016 \\
(1.089)\end{array}$ & $\begin{array}{l}0.494 \\
(0.205)\end{array}$ \\
\hline Total expenditure (000) & $\begin{array}{l}108.031 \\
(58.704)\end{array}$ & $\begin{array}{l}1.343 \\
(5.894)\end{array}$ & $\begin{array}{l}1.368 \\
(5.894)\end{array}$ & $\begin{array}{l}0.025 \\
(0.000)\end{array}$ \\
\hline $\begin{array}{l}\text { F-stat of test of Joint Significance } \\
\text { p-value of test of Joint Significance }\end{array}$ & & $\begin{array}{l}0.498 \\
0.916\end{array}$ & $\begin{array}{l}0.213 \\
0.998\end{array}$ & $\begin{array}{l}0.449 \\
0.990\end{array}$ \\
\hline
\end{tabular}

${ }^{*}: p<0.1 ;^{* *}: p<0.05 ;^{* * *}: p<0.01$. Source: Authors' calculation from NE-Baseline survey and NGF eligibility survey. 
Table 4: Timeline of Data Collection

\begin{tabular}{|c|c|c|}
\hline Date & Project Task & Evaluation Task \\
\hline Early February 2010 & NGF identifies subjects & $\begin{array}{l}\text { NGF eligibility survey collects } \\
\text { background information on } \\
\text { subjects and associated carpet } \\
\text { establishments }\end{array}$ \\
\hline Late Feb / Early March 2010 & & NE collects baseline survey data \\
\hline Late March 2010 & $\begin{array}{l}\text { Treatment group assignment done } \\
\text { and NGF notifies subjects of their } \\
\text { status }\end{array}$ & \\
\hline Late April 2010 & School year starts & \\
\hline May 2010 & $\begin{array}{l}\text { NGF begins collecting monthly } \\
\text { school attendance data }\end{array}$ & \\
\hline September 2010 & & NE midyear survey \\
\hline February 2011 & $\begin{array}{l}\text { NGF ends collecting monthly } \\
\text { school attendance data }\end{array}$ & \\
\hline March 2011 & $\begin{array}{l}\text { NGF makes final disbursements. } \\
\text { Subjects take final exams }\end{array}$ & \\
\hline Late April / May 2011 & & NE yearend survey \\
\hline August 2012 & & NE followup survey \\
\hline
\end{tabular}

NGF: Nepal Goodweave Foundation; NE: New ERA Ltd.

Table 5: Attrition

\begin{tabular}{lccc}
\hline \hline & & & \\
Data Source & Control & Scholarship & Stipend \\
\hline NE Baseline, 3/10 & 220 & 220 & 220 \\
NE Midterm, 9/10 & 207 & 215 & 216 \\
NE Yearend, 5/11 & 219 & 218 & 218 \\
NE Followup, 8/12 & 217 & 217 & 216 \\
NGF School Records, 9/10 & 220 & 218 & 217 \\
NGF School Records, 3/11 & 220 & 218 & 217 \\
\hline \hline
\end{tabular}


Table 6: Treatment Effects on Schooling Outcomes during year of support

\begin{tabular}{|c|c|c|c|c|}
\hline & $\begin{array}{l}\text { Control } \\
\text { mean/(sd) } \\
(1)\end{array}$ & $\begin{array}{l}\text { Scholarship } \\
\text {-Control } \\
\text { b/(se) } \\
(2)\end{array}$ & $\begin{array}{l}\text { Stipend } \\
\text {-Control } \\
\mathrm{b} /(\mathrm{se}) \\
(3)\end{array}$ & $\begin{array}{l}\text { Stipend } \\
\text {-Scholarship } \\
\text { b/(F) } \\
\text { (4) }\end{array}$ \\
\hline Attended school during school year & $\begin{array}{l}0.918 \\
(0.275)\end{array}$ & $\begin{array}{l}0.023 \\
(0.029)\end{array}$ & $\begin{array}{l}0.049^{* *} \\
(0.019)\end{array}$ & $\begin{array}{l}0.027 \\
(1.344)\end{array}$ \\
\hline Attendance rate & $\begin{array}{l}0.811 \\
(0.281)\end{array}$ & $\begin{array}{l}0.033 \\
(0.026)\end{array}$ & $\begin{array}{l}0.102^{* * *} \\
(0.021)\end{array}$ & $\begin{array}{l}0.069^{* * *} \\
(13.396)\end{array}$ \\
\hline Sat for final exams & $\begin{array}{l}0.873 \\
(0.334)\end{array}$ & $\begin{array}{l}0.017 \\
(0.034)\end{array}$ & $\begin{array}{l}0.088^{* * *} \\
(0.026)\end{array}$ & $\begin{array}{l}0.071^{* * *} \\
(7.711)\end{array}$ \\
\hline Score in final exams (standardized) & $\begin{array}{l}0.000 \\
(1.000)\end{array}$ & $\begin{array}{l}0.116 \\
(0.086)\end{array}$ & $\begin{array}{l}0.184^{* *} \\
(0.087)\end{array}$ & $\begin{array}{l}0.069 \\
(0.648)\end{array}$ \\
\hline Failed current grade & $\begin{array}{l}0.135 \\
(0.343)\end{array}$ & $\begin{array}{l}-0.064^{*} \\
(0.035)\end{array}$ & $\begin{array}{l}-0.062^{* *} \\
(0.029)\end{array}$ & $\begin{array}{l}0.002 \\
(0.005)\end{array}$ \\
\hline
\end{tabular}

* : $p<0.1 ;^{* *}: p<0.05 ;^{* * *}: p<0.01$. Each row is from a different regression with the row variable as the dependent variable. All regressions include age $\times$ gender fixed effects as well as dummies for randomization strata and controls for baseline time allocation. Standard errors are clustered by establishment. Column (1) is the mean and standard deviation of the row variable for the control group. Column (2) indicates the coefficient and standard error on an indicator for scholarship treatment group. Column (3) indicates the coefficient and standard error on an indicator for stipend treatment group. Column (4) presents difference between coefficients in columns (2) and (3) and F-stat for the test of null that stipend group differs from the scholarship group. The first row is based on parental report and the rest comes from school report from NGF.

Table 7: Treatment Effects on Schooling Outcomes after year of support

\begin{tabular}{lllll}
\hline \hline & Control & $\begin{array}{l}\text { Scholarship } \\
\text {-Control }\end{array}$ & $\begin{array}{l}\text { Stipend } \\
\text {-Control }\end{array}$ & $\begin{array}{l}\text { Stipend } \\
\text {-Scholarship } \\
\mathrm{b} /(\mathrm{F})\end{array}$ \\
& $\begin{array}{l}\text { mean } /(\mathrm{sd}) \\
\mathrm{b} /(\mathrm{se})\end{array}$ & $(2)$ & $(3)$ & $(4)$ \\
\hline Enrolled in School (Year +1$)$ & $(1)$ & -0.002 & 0.013 & 0.016 \\
& $(0.254)$ & $(0.023)$ & $(0.019)$ & $(0.521)$ \\
Passed enrolled grade (Year + 1) & 0.915 & -0.003 & -0.023 & -0.019 \\
& $(0.280)$ & $(0.027)$ & $(0.026)$ & $(0.482)$ \\
Enrolled in School (Year +2$)$ & 0.816 & 0.048 & 0.013 & -0.034 \\
Attended school in current month $($ Year +2$)$ & $(0.389)$ & $(0.034)$ & $(0.032)$ & $(1.044)$ \\
& 0.779 & 0.050 & 0.012 & -0.039 \\
Completed Years of Schooling (Year +2$)$ & $(0.416)$ & $(0.037)$ & $(0.034)$ & $(1.065)$ \\
& 6.645 & -0.129 & 0.065 & 0.194 \\
& $(2.295)$ & $(0.137)$ & $(0.123)$ & $(2.458)$ \\
\hline \hline
\end{tabular}

${ }^{*}: p<0.1 ;^{* *}: p<0.05 ;^{* * *}: p<0.01$. Each row is from a different regression with the row variable as the dependent variable. All regressions include age $\times$ gender fixed effects as well as dummies for randomization strata and controls for baseline time allocation. Standard errors are clustered by establishment. Column (1) is the mean and standard deviation of the row variable for the control group. Column (2) indicates the coefficient and standard error on an indicator for scholarship treatment group. Column (3) indicates the coefficient and standard error on an indicator for stipend treatment group. Column (4) presents difference between coefficients in columns (2) and (3) and F-stat for the test of null that stipend group differs from the scholarship group. All variables are reported by parents during the Followup Survey. 
Table 8: Treatment Effects on Schooling Outcomes by Gender

\begin{tabular}{|c|c|c|c|c|}
\hline & $\begin{array}{l}\text { Control } \\
\text { mean/(sd) } \\
(1)\end{array}$ & $\begin{array}{l}\text { Scholarship } \\
\text {-Control } \\
\text { b/(se) } \\
(2) \\
\end{array}$ & $\begin{array}{l}\text { Stipend } \\
\text {-Control } \\
\mathrm{b} /(\mathrm{se}) \\
(3) \\
\end{array}$ & $\begin{array}{l}\text { Stipend - } \\
\text { Scholarship } \\
\text { b/(F) } \\
(4) \\
\end{array}$ \\
\hline \multicolumn{5}{|l|}{ Boys } \\
\hline Attended school during school year & $\begin{array}{l}0.911 \\
(0.286)\end{array}$ & $\begin{array}{l}0.045 \\
(0.043)\end{array}$ & $\begin{array}{l}0.038 \\
(0.029)\end{array}$ & $\begin{array}{l}-0.007 \\
(0.045)\end{array}$ \\
\hline Attendance rate & $\begin{array}{l}0.801 \\
(0.278)\end{array}$ & $\begin{array}{l}0.041 \\
(0.041)\end{array}$ & $\begin{array}{l}0.094^{* * *} \\
(0.030)\end{array}$ & $\begin{array}{l}0.053^{*} \\
(3.011)\end{array}$ \\
\hline Sat for final exams & $\begin{array}{l}0.871 \\
(0.337)\end{array}$ & $\begin{array}{l}0.019 \\
(0.053)\end{array}$ & $\begin{array}{l}0.073^{*} \\
(0.037)\end{array}$ & $\begin{array}{l}0.054 \\
(1.773)\end{array}$ \\
\hline Score in final exams (standardized) & $\begin{array}{l}-0.040 \\
(0.979)\end{array}$ & $\begin{array}{l}0.169 \\
(0.124)\end{array}$ & $\begin{array}{l}0.123 \\
(0.129)\end{array}$ & $\begin{array}{l}-0.046 \\
(0.156)\end{array}$ \\
\hline Failed current grade & $\begin{array}{l}0.136 \\
(0.345)\end{array}$ & $\begin{array}{l}-0.071 \\
(0.051)\end{array}$ & $\begin{array}{l}-0.041 \\
(0.048)\end{array}$ & $\begin{array}{l}0.030 \\
(0.683)\end{array}$ \\
\hline Enrolled in School (Year + 1) & $\begin{array}{l}0.930 \\
(0.256)\end{array}$ & $\begin{array}{l}-0.008 \\
(0.043)\end{array}$ & $\begin{array}{l}0.024 \\
(0.032)\end{array}$ & $\begin{array}{l}0.032 \\
(0.803)\end{array}$ \\
\hline Passed enrolled grade $($ Year +1$)$ & $\begin{array}{l}0.900 \\
(0.302)\end{array}$ & $\begin{array}{l}-0.032 \\
(0.056)\end{array}$ & $\begin{array}{l}-0.036 \\
(0.053)\end{array}$ & $\begin{array}{l}-0.003 \\
(0.004)\end{array}$ \\
\hline Enrolled in School $($ Year +2$)$ & $\begin{array}{l}0.810 \\
(0.394)\end{array}$ & $\begin{array}{l}0.018 \\
(0.055)\end{array}$ & $\begin{array}{l}-0.006 \\
(0.056)\end{array}$ & $\begin{array}{l}-0.024 \\
(0.188)\end{array}$ \\
\hline Attended school in current month $($ Year +2$)$ & $\begin{array}{l}0.770 \\
(0.423)\end{array}$ & $\begin{array}{l}0.030 \\
(0.054)\end{array}$ & $\begin{array}{l}-0.047 \\
(0.056)\end{array}$ & $\begin{array}{l}-0.077 \\
(1.741)\end{array}$ \\
\hline Completed Years of Schooling $($ Year +2$)$ & $\begin{array}{l}6.790 \\
(2.311) \\
\end{array}$ & $\begin{array}{l}-0.367 \\
(0.248) \\
\end{array}$ & $\begin{array}{l}-0.051 \\
(0.174) \\
\end{array}$ & $\begin{array}{l}0.316 \\
(2.560) \\
\end{array}$ \\
\hline Girls & & & & \\
\hline Attended school during school year & $\begin{array}{l}0.924 \\
(0.267)\end{array}$ & $\begin{array}{l}0.004 \\
(0.040)\end{array}$ & $\begin{array}{l}0.055^{*} \\
(0.030)\end{array}$ & $\begin{array}{l}0.050^{*} \\
(3.031)\end{array}$ \\
\hline Attendance rate & $\begin{array}{l}0.820 \\
(0.284)\end{array}$ & $\begin{array}{l}0.030 \\
(0.030)\end{array}$ & $\begin{array}{l}0.108^{* * *} \\
(0.027)\end{array}$ & $\begin{array}{l}0.078^{* * *} \\
(16.587)\end{array}$ \\
\hline Sat for final exams & $\begin{array}{l}0.874 \\
(0.333)\end{array}$ & $\begin{array}{l}0.016 \\
(0.039)\end{array}$ & $\begin{array}{l}0.097^{* * *} \\
(0.033)\end{array}$ & $\begin{array}{l}0.081^{* * *} \\
(8.150)\end{array}$ \\
\hline Score in final exams (standardized) & $\begin{array}{l}0.034 \\
(1.021)\end{array}$ & $\begin{array}{l}0.099 \\
(0.135)\end{array}$ & $\begin{array}{l}0.278^{* *} \\
(0.122)\end{array}$ & $\begin{array}{l}0.179 \\
(1.888)\end{array}$ \\
\hline Failed current grade & $\begin{array}{l}0.135 \\
(0.343)\end{array}$ & $\begin{array}{l}-0.063 \\
(0.043)\end{array}$ & $\begin{array}{l}-0.089^{* *} \\
(0.034)\end{array}$ & $\begin{array}{l}-0.026 \\
(0.497)\end{array}$ \\
\hline Enrolled in School (Year + 1) & $\begin{array}{l}0.932 \\
(0.253)\end{array}$ & $\begin{array}{l}0.002 \\
(0.025)\end{array}$ & $\begin{array}{l}0.004 \\
(0.023)\end{array}$ & $\begin{array}{l}0.003 \\
(0.014)\end{array}$ \\
\hline Passed enrolled grade $($ Year +1$)$ & $\begin{array}{l}0.927 \\
(0.262)\end{array}$ & $\begin{array}{l}0.011 \\
(0.035)\end{array}$ & $\begin{array}{l}-0.028 \\
(0.034)\end{array}$ & $\begin{array}{l}-0.039 \\
(1.478)\end{array}$ \\
\hline Enrolled in School $($ Year +2$)$ & $\begin{array}{l}0.821 \\
(0.385)\end{array}$ & $\begin{array}{l}0.064 \\
(0.046)\end{array}$ & $\begin{array}{l}0.022 \\
(0.043)\end{array}$ & $\begin{array}{l}-0.042 \\
(1.234)\end{array}$ \\
\hline Attended school in current month $($ Year +2$)$ & $\begin{array}{l}0.786 \\
(0.412)\end{array}$ & $\begin{array}{l}0.055 \\
(0.049)\end{array}$ & $\begin{array}{l}0.046 \\
(0.042)\end{array}$ & $\begin{array}{l}-0.008 \\
(0.047)\end{array}$ \\
\hline Completed Years of Schooling (Year +2$)$ & $\begin{array}{l}6.521 \\
(2.284)\end{array}$ & $\begin{array}{l}0.041 \\
(0.214)\end{array}$ & $\begin{array}{l}0.138 \\
(0.194)\end{array}$ & $\begin{array}{l}0.097 \\
(0.310)\end{array}$ \\
\hline
\end{tabular}

${ }^{*}: p<0.1 ;^{* *}: p<0.05 ;^{* * *}: p<0.01$. Each row is from a different regression with the row variable as the dependent variable. All regressions include age $\times$ gender fixed effects as well as dummies for randomization strata and controls for baseline time allocation. Standard errors are clustered by establishment. The top panel refers to boys and and the bottom panel refers to girls. Column (1) is the mean and standard deviation of the row variable for the control group. Column (2) indicates the coefficient and standard error on an indicator for scholarship treatment group. Column (3) indicates the coefficient and standard error on an indicator for stipend treatment group. Column (4) presents difference between coefficients in columns (2) and (3) and F-stat for the test of null that stipend group differs from the scholarship group. Variable sources are as described in previous tables. 
Table 9: Treatment Effects on Child Labor

\begin{tabular}{|c|c|c|c|c|}
\hline & $\begin{array}{l}\text { Control } \\
\text { mean/(sd) } \\
(1)\end{array}$ & $\begin{array}{l}\text { Scholarship } \\
\text {-Control } \\
\text { b/(se) } \\
(2)\end{array}$ & $\begin{array}{l}\text { Stipend } \\
\text {-Control } \\
\mathrm{b} /(\mathrm{se}) \\
(3)\end{array}$ & $\begin{array}{l}\text { Stipend } \\
\text {-Scholarship } \\
\text { b/(F) } \\
(4)\end{array}$ \\
\hline Child weaved in past 7 days (yearend) & $\begin{array}{l}0.073 \\
(0.261)\end{array}$ & $\begin{array}{l}-0.011 \\
(0.025)\end{array}$ & $\begin{array}{l}-0.043^{* *} \\
(0.020)\end{array}$ & $\begin{array}{l}-0.032^{*} \\
(3.105)\end{array}$ \\
\hline Hours weaved in past 7 days (yearend) & $\begin{array}{l}2.178 \\
(9.431)\end{array}$ & $\begin{array}{l}-0.585 \\
(0.990)\end{array}$ & $\begin{array}{l}-1.497^{*} \\
(0.761)\end{array}$ & $\begin{array}{l}-0.912 \\
(2.220)\end{array}$ \\
\hline Child weaved in past 12 months (yearend) & $\begin{array}{l}0.114 \\
(0.319)\end{array}$ & $\begin{array}{l}-0.007 \\
(0.028)\end{array}$ & $\begin{array}{l}-0.055^{* *} \\
(0.027)\end{array}$ & $\begin{array}{l}-0.048^{*} \\
(2.889)\end{array}$ \\
\hline Child weaved in past 30 days (Year +2 ) & $\begin{array}{l}0.092 \\
(0.290)\end{array}$ & $\begin{array}{l}-0.011 \\
(0.024)\end{array}$ & $\begin{array}{l}-0.016 \\
(0.026)\end{array}$ & $\begin{array}{l}-0.006 \\
(0.049)\end{array}$ \\
\hline Child weaved in past 12 months (Year +2 ) & $\begin{array}{l}0.129 \\
(0.336)\end{array}$ & $\begin{array}{l}-0.009 \\
(0.026)\end{array}$ & $\begin{array}{l}-0.026 \\
(0.028)\end{array}$ & $\begin{array}{l}-0.017 \\
(0.396)\end{array}$ \\
\hline
\end{tabular}

${ }^{*}: p<0.1 ;^{* *}: p<0.05 ;^{* * *}: p<0.01$. Each row is from a different regression with the row variable as the dependent variable. All regressions include age $\times$ gender fixed effects as well as dummies for randomization strata and controls for baseline time allocation. Standard errors are clustered by establishment. Column (1) is the mean and standard deviation of the row variable for the control group. Column (2) indicates the coefficient and standard error on an indicator for scholarship treatment group. Column (3) indicates the coefficient and standard error on an indicator for stipend treatment group. Column (4) presents difference between coefficients in columns (2) and (3) and F-stat for the test of null that stipend group differs from the scholarship group. All variables are reported during the Followup and Yearend Survey. 
Table 10: Treatment Effects on Child Labor by Gender

\begin{tabular}{|c|c|c|c|c|}
\hline & $\begin{array}{l}\text { Control } \\
\text { mean/(sd) } \\
(1)\end{array}$ & $\begin{array}{l}\text { Scholarship } \\
\text {-Control } \\
\text { b/(se) } \\
(2)\end{array}$ & $\begin{array}{l}\text { Stipend } \\
\text {-Control } \\
\text { b/(se) } \\
(3)\end{array}$ & $\begin{array}{l}\text { Stipend - } \\
\text { Scholarship } \\
\text { b/(F) } \\
\text { (4) }\end{array}$ \\
\hline \multicolumn{5}{|l|}{ Boys } \\
\hline Child weaved in past 7 days (yearend) & $\begin{array}{l}0.040 \\
(0.196)\end{array}$ & $\begin{array}{l}0.013 \\
(0.024)\end{array}$ & $\begin{array}{l}-0.012 \\
(0.020)\end{array}$ & $\begin{array}{l}-0.025 \\
(0.756)\end{array}$ \\
\hline Hours weaved in past 7 days (yearend) & $\begin{array}{l}1.129 \\
(6.067)\end{array}$ & $\begin{array}{l}0.013 \\
(0.539)\end{array}$ & $\begin{array}{l}-0.003 \\
(0.841)\end{array}$ & $\begin{array}{l}-0.017 \\
(0.001)\end{array}$ \\
\hline Child weaved in past 12 months (yearend) & $\begin{array}{l}0.059 \\
(0.238)\end{array}$ & $\begin{array}{l}0.034 \\
(0.033)\end{array}$ & $\begin{array}{l}0.006 \\
(0.030)\end{array}$ & $\begin{array}{l}-0.028 \\
(0.476)\end{array}$ \\
\hline Child weaved in past 30 days $($ Year +2$)$ & $\begin{array}{l}0.050 \\
(0.219)\end{array}$ & $\begin{array}{l}0.023 \\
(0.029)\end{array}$ & $\begin{array}{l}-0.016 \\
(0.024)\end{array}$ & $\begin{array}{l}-0.039 \\
(1.609)\end{array}$ \\
\hline Child weaved in past 12 months $($ Year +2$)$ & $\begin{array}{l}0.060 \\
(0.239)\end{array}$ & $\begin{array}{l}0.034 \\
(0.033)\end{array}$ & $\begin{array}{l}-0.014 \\
(0.028)\end{array}$ & $\begin{array}{l}-0.048 \\
(2.287) \\
\end{array}$ \\
\hline \multicolumn{5}{|l|}{ Girls } \\
\hline Child weaved in past 7 days (yearend) & $\begin{array}{l}0.102 \\
(0.304)\end{array}$ & $\begin{array}{l}-0.033 \\
(0.038)\end{array}$ & $\begin{array}{l}-0.076^{* *} \\
(0.031)\end{array}$ & $\begin{array}{l}-0.043 \\
(2.619)\end{array}$ \\
\hline Hours weaved in past 7 days (yearend) & $\begin{array}{l}3.076 \\
(11.510)\end{array}$ & $\begin{array}{l}-0.932 \\
(1.709)\end{array}$ & $\begin{array}{l}-2.815^{* *} \\
(1.210)\end{array}$ & $\begin{array}{l}-1.883^{* *} \\
(3.945)\end{array}$ \\
\hline Child weaved in past 12 months (yearend) & $\begin{array}{l}0.161 \\
(0.369)\end{array}$ & $\begin{array}{l}-0.037 \\
(0.042)\end{array}$ & $\begin{array}{l}-0.103^{* *} \\
(0.042)\end{array}$ & $\begin{array}{l}-0.066 \\
(2.688)\end{array}$ \\
\hline Child weaved in past 30 days $($ Year +2$)$ & $\begin{array}{l}0.128 \\
(0.336)\end{array}$ & $\begin{array}{l}-0.045 \\
(0.039)\end{array}$ & $\begin{array}{l}-0.023 \\
(0.042)\end{array}$ & $\begin{array}{l}0.021 \\
(0.284)\end{array}$ \\
\hline Child weaved in past 12 months (Year +2$)$ & $\begin{array}{l}0.188 \\
(0.392)\end{array}$ & $\begin{array}{l}-0.053 \\
(0.042)\end{array}$ & $\begin{array}{l}-0.046 \\
(0.047)\end{array}$ & $\begin{array}{l}0.007 \\
(0.025)\end{array}$ \\
\hline
\end{tabular}

${ }^{*}: p<0.1 ;^{* *}: p<0.05 ;^{* * *}: p<0.01$. Each row is from a different regression with the row variable as the dependent variable. All regressions include age $\times$ gender fixed effects as well as dummies for randomization strata and controls for baseline time allocation. Standard errors are clustered by establishment. The top panel refers to boys and and the bottom panel refers to girls. Column (1) is the mean and standard deviation of the row variable for the control group. Column (2) indicates the coefficient and standard error on an indicator for scholarship treatment group. Column (3) indicates the coefficient and standard error on an indicator for stipend treatment group. Column (4) presents difference between coefficients in columns (2) and (3) and F-stat for the test of null that stipend group differs from the scholarship group. Variable sources are as described in previous tables. 
Table 11: Treatment Effect on Household Spending

\begin{tabular}{|c|c|c|c|c|}
\hline & $\begin{array}{l}\text { Control } \\
\text { mean } /(\mathrm{sd}) \\
(1)\end{array}$ & $\begin{array}{l}\text { Scholarship } \\
\text {-Control } \\
\text { b/(se) } \\
(2)\end{array}$ & $\begin{array}{l}\text { Stipend } \\
\text {-Control } \\
\text { b/(se) } \\
(3)\end{array}$ & $\begin{array}{l}\text { Stipend } \\
\text {-Scholarship } \\
\text { b/(F) } \\
(4)\end{array}$ \\
\hline Household reports savings & $\begin{array}{l}0.169 \\
(0.376)\end{array}$ & $\begin{array}{l}0.023 \\
(0.033)\end{array}$ & $\begin{array}{l}-0.005 \\
(0.039)\end{array}$ & $\begin{array}{l}-0.029 \\
(0.492)\end{array}$ \\
\hline Amount savings (NPR) & $\begin{array}{l}391.781 \\
(1611.776)\end{array}$ & $\begin{array}{l}-69.713 \\
(133.050)\end{array}$ & $\begin{array}{l}-132.743 \\
(135.294)\end{array}$ & $\begin{array}{l}-63.030 \\
(0.442)\end{array}$ \\
\hline Log(education expenses, scholarship inc) & $\begin{array}{l}9.112 \\
(1.886)\end{array}$ & $\begin{array}{l}0.510^{* * *} \\
(0.159)\end{array}$ & $\begin{array}{l}0.549^{* * *} \\
(0.150)\end{array}$ & $\begin{array}{l}0.039 \\
(0.175)\end{array}$ \\
\hline $\log ($ food expenses, stipend inc) & $\begin{array}{l}10.973 \\
(0.323)\end{array}$ & $\begin{array}{l}0.028 \\
(0.031)\end{array}$ & $\begin{array}{l}0.166^{* * *} \\
(0.027)\end{array}$ & $\begin{array}{l}0.139^{* * *} \\
(20.914)\end{array}$ \\
\hline Log(total expenses, benefits inc) & $\begin{array}{l}11.663 \\
(0.367)\end{array}$ & $\begin{array}{l}0.048 \\
(0.031)\end{array}$ & $\begin{array}{l}0.138^{* * *} \\
(0.028)\end{array}$ & $\begin{array}{l}0.090^{* * *} \\
(8.961)\end{array}$ \\
\hline Average Adult hours working & $\begin{array}{l}13.438 \\
(19.298)\end{array}$ & $\begin{array}{l}-2.080 \\
(1.283)\end{array}$ & $\begin{array}{l}-3.257^{* *} \\
(1.563)\end{array}$ & $\begin{array}{l}-1.177 \\
(0.557)\end{array}$ \\
\hline
\end{tabular}

* : $p<0.1 ;^{* *}: p<0.05$ *** $^{* *} p<0.01$. Each row is from a different regression with the row variable as the dependent variable. All regressions include age $\times$ gender fixed effects as well as dummies for randomization strata and controls for baseline time allocation. Standard errors are clustered by establishment. Column (1) is the mean and standard deviation of the row variable for the control group. Column (2) indicates the coefficient and standard error on an indicator for scholarship treatment group. Column (3) indicates the coefficient and standard error on an indicator for stipend treatment group. Column (4) presents difference between coefficients in columns (2) and (3) and F-stat for the test of null that stipend group differs from the scholarship group. All variables are reported in Yearend Survey. 
Table 12: Within household Spillovers on Control Children

\begin{tabular}{|c|c|c|c|}
\hline & $\begin{array}{l}\text { Number of Sub- } \\
\text { jects in HH } \\
\text { b/(se) } \\
\text { (1) }\end{array}$ & $\begin{array}{l}\text { Has Scholarship } \\
\text { child in HH } \\
\text { b/(se) } \\
(2)\end{array}$ & $\begin{array}{l}\text { Has Stipend } \\
\text { child in } \mathrm{HH} \\
\mathrm{b} /(\mathrm{se}) \\
(3)\end{array}$ \\
\hline Attended school during school year & $\begin{array}{l}-0.104 \\
(0.069)\end{array}$ & $\begin{array}{l}0.156^{* *} \\
(0.072)\end{array}$ & $\begin{array}{l}0.171^{* *} \\
(0.086)\end{array}$ \\
\hline Attendance rate & $\begin{array}{l}0.045 \\
(0.055)\end{array}$ & $\begin{array}{l}0.031 \\
(0.061)\end{array}$ & $\begin{array}{l}0.017 \\
(0.072)\end{array}$ \\
\hline Sat for final exams & $\begin{array}{l}0.062 \\
(0.058)\end{array}$ & $\begin{array}{l}0.062 \\
(0.071)\end{array}$ & $\begin{array}{l}0.037 \\
(0.078)\end{array}$ \\
\hline Score in final exams (standardized) & $\begin{array}{l}-0.251 \\
(0.161)\end{array}$ & $\begin{array}{l}0.013 \\
(0.218)\end{array}$ & $\begin{array}{l}0.234 \\
(0.224)\end{array}$ \\
\hline Failed current grade & $\begin{array}{l}0.065 \\
(0.055)\end{array}$ & $\begin{array}{l}-0.036 \\
(0.078)\end{array}$ & $\begin{array}{l}-0.078 \\
(0.084)\end{array}$ \\
\hline Enrolled in School $($ Year +1$)$ & $\begin{array}{l}-0.038 \\
(0.054)\end{array}$ & $\begin{array}{l}0.000 \\
(0.054)\end{array}$ & $\begin{array}{l}0.068 \\
(0.072)\end{array}$ \\
\hline Passed enrolled grade $($ Year +1$)$ & $\begin{array}{l}-0.043 \\
(0.055)\end{array}$ & $\begin{array}{l}0.095 \\
(0.060)\end{array}$ & $\begin{array}{l}0.037 \\
(0.090)\end{array}$ \\
\hline Enrolled in School $($ Year +2$)$ & $\begin{array}{l}-0.077 \\
(0.058)\end{array}$ & $\begin{array}{l}0.064 \\
(0.070)\end{array}$ & $\begin{array}{l}0.106 \\
(0.075)\end{array}$ \\
\hline Attended school in current month (Year +2$)$ & $\begin{array}{l}-0.109 \\
(0.074)\end{array}$ & $\begin{array}{l}0.066 \\
(0.091)\end{array}$ & $\begin{array}{l}0.155^{*} \\
(0.092)\end{array}$ \\
\hline Completed Years of Schooling (Year +2$)$ & $\begin{array}{l}0.092 \\
(0.225)\end{array}$ & $\begin{array}{l}0.296 \\
(0.370)\end{array}$ & $\begin{array}{l}0.178 \\
(0.391)\end{array}$ \\
\hline Child weaved in past 7 days (yearend) & $\begin{array}{l}0.074 \\
(0.054)\end{array}$ & $\begin{array}{l}0.013 \\
(0.053)\end{array}$ & $\begin{array}{l}-0.078 \\
(0.053)\end{array}$ \\
\hline Hours weaved in past 7 days (yearend) & $\begin{array}{l}3.009 \\
(2.081)\end{array}$ & $\begin{array}{l}-0.895 \\
(2.162)\end{array}$ & $\begin{array}{l}-2.527 \\
(1.915)\end{array}$ \\
\hline Child weaved in past 12 months (yearend) & $\begin{array}{l}0.033 \\
(0.051)\end{array}$ & $\begin{array}{l}0.089 \\
(0.055)\end{array}$ & $\begin{array}{l}-0.022 \\
(0.055)\end{array}$ \\
\hline Child weaved in past 30 days $($ Year +2$)$ & $\begin{array}{l}0.003 \\
(0.036)\end{array}$ & $\begin{array}{l}-0.006 \\
(0.047)\end{array}$ & $\begin{array}{l}0.008 \\
(0.042)\end{array}$ \\
\hline Child weaved in past 12 months (Year +2$)$ & $\begin{array}{l}-0.041 \\
(0.042)\end{array}$ & $\begin{array}{l}0.100^{*} \\
(0.058)\end{array}$ & $\begin{array}{l}0.055 \\
(0.044)\end{array}$ \\
\hline
\end{tabular}

${ }^{*}: p<0.1 ;^{* *}: p<0.05 ;^{* * *}: p<0.01$. Sample restricted to control children only. Each row is from a different regression with the row variable as the dependent variable. All regressions include age $\times$ gender fixed effects as well as dummies for randomization strata and controls for baseline time allocation. Standard errors are clustered by establishment. Column (1) indicates the coefficient and standard error on the number of study subjects in the household. Column (2) indicates the coefficient and standard error on an indicator for whether the household has a child from scholarship group. Column (3) indicates the coefficient and standard error on an indicator for whether the household has a child from stipend group. Variable sources are as in previous tables. 